\title{
What Matters in Corporate Governance?
}

\section{Citation}

Lucian A. Bebchuk, Alma Cohen \& Allen Ferrell, What Matters in Corporate Governance?, 22 Rev. Fin. Stud. 783 (2009).

\section{Published Version}

http://rfs.oxfordjournals.org/content/22/2/783.full.pdf

\section{Permanent link}

http://nrs.harvard.edu/urn-3:HUL.InstRepos:11224528

\section{Terms of Use}

This article was downloaded from Harvard University's DASH repository, and is made available under the terms and conditions applicable to Open Access Policy Articles, as set forth at http:// nrs.harvard.edu/urn-3:HUL.InstRepos:dash.current.terms-of-use\#OAP

\section{Share Your Story}

The Harvard community has made this article openly available.

Please share how this access benefits you. Submit a story.

Accessibility 
ISSN 1045-6333

\section{HARVARD}

JOHN M. OLin CENTER FOR LAW, ECONOMICS, AND BUSINESS

WHAT MATTERS IN

CORPORATE GOVERNANCE?

Lucian Bebchuk, Alma Cohen, and Allen Ferrell

Discussion Paper No. 491

$09 / 2004$

As revised for publication in The Review of Financial Studies

Harvard Law School

Cambridge, MA 02138

This paper can be downloaded without charge from:

The Harvard John M. Olin Discussion Paper Series:

http://www.law.harvard.edu/programs/olin_center/

The Social Science Research Network Electronic Paper Collection:

http://papers.ssrn.com/abstract_id=593423

This paper is also a discussion paper of the

John M. Olin Center's Program on Corporate Governance 


\title{
What Matters in Corporate Governance?
}

\author{
Lucian Bebchuk, $^{*}$ Alma Cohen, ${ }^{* *}$ and Allen Ferrell ${ }^{* * *}$
}

\begin{abstract}
$\underline{\text { Abstract }}$
We investigate the relative importance of the 24 provisions followed by the Investor Responsibility Research Center (IRRC) and included in the Gompers, Ishii and Metrick (2003) governance index. We put forward an entrenchment index based on six provisions: staggered boards, limits to shareholder bylaw amendments, poison pills, golden parachutes, and supermajority requirements for mergers and charter amendments. We find that increases in the index level are monotonically associated with economically significant reductions in firm valuation as well as large negative abnormal returns during the 1990-2003 period. The other eighteen IRRC provisions not in our entrenchment index were uncorrelated with either reduced firm valuation or negative abnormal returns.
\end{abstract}

Key words: Corporate governance, agency costs, boards, directors, takeovers, tender offers, mergers and acquisitions, proxy fights, defensive tactics, entrenchment, anti-takeover provisions, staggered boards, corporate charters, corporate bylaws, golden parachutes, poison pills.

JEL Classification: G30, G34, K22

\footnotetext{
*Harvard Law School and NBER (bebchuk@law.harvard.edu).

** Tel-Aviv University Department of Economics, NBER, and Harvard Law School Olin Center for Law, Economics and Business (acohen@post.tau.ac.il)

*** Harvard Law School and ECGI (fferrell@law.harvard.edu).

For helpful suggestions and discussions, we are grateful to Bernie Black, Victor Chernozhukov, Martijn Cremers, Ray Fisman, Yaniv Grinstein, Robert Marquez, Andrew Metrick, Guhan Subramanian, Greg Taxin, Manuel Trajtenberg, Yishay Yafeh, Rose Zhao, Michael Weisbach (the editor), an anonymous referee, and conference participants at the NBER, Washington University, the Oxford Saïd Business School, Tel-Aviv University, the Bank of Israel, and the ALEA annual meeting. Our work benefited from the financial support of the Nathan Cummins Foundation, the Guggenheim Foundation, the Harvard Law School John M. Olin Center for Law, Economics, and Business, the Harvard Milton fund, and the Harvard Program on Corporate Governance.

For those wishing to use the entrenchment index put forward in this paper in their research, data on firms' entrenchment index levels is available at http://www.law.harvard.edu/faculty/bebchuk/data.shtml. A list of over 75 studies already using the index is available at http://www.law.harvard.edu/faculty/bebchuk/studies.shtml.
} 


\section{INTRODUCTION}

There is now widespread recognition, as well as growing empirical evidence, that corporate governance arrangements can substantially affect shareholders. But which provisions, among the many provisions firms have and outside observers follow, are the ones that play a key role in the link between corporate governance and firm value? This is the question we investigate in this paper.

An analysis that seeks to identify which provisions matter should not look at provisions in isolation without controlling for other corporate governance provisions that might also influence firm value. Thus, it is desirable to look at a universe of provisions together. We focus in this paper on the universe of provisions that the Investor Responsibility Research Center (IRRC) monitors for institutional investors and researchers interested in corporate governance. The IRRC follows 24 governance provisions (the IRRC provisions) that appear beneficial to management, and which may or may not be harmful to shareholders. Prior research has identified a relationship between the IRRC provisions in the aggregate and firm value. In an influential article, Gompers, Ishii, and Metrick (2003) found that a broad index based on these 24 provisions, giving each IRRC provision equal weight, was negatively correlated with firm value, as measured by Tobin's Q, as well as stockholder returns during the decade of the 1990s. Not surprisingly, a substantial amount of subsequent research has utilized this index (the "GIM index”) as a measure of the quality of firms' governance provisions. ${ }^{1}$

There is no a priori reason, of course, to expect that all the 24 IRRC provisions contribute to the documented correlation between the IRRC provisions in the aggregate and Tobin's Q, as well as stock returns in the 1990s. ${ }^{2}$ Some provisions might have little relevance, and some provisions might even be positively correlated with firm value. Among those provisions that are negatively correlated with firm value or stock returns, some might be more so than others. Furthermore, some provisions might be at least partly the endogenous product of the allocation of power

\footnotetext{
${ }^{1}$ See, for example, Harford, Mansi, and Maxwell (2008); Klock, Mansi, and Maxwell (2005); Amit and Villalonga (2006); John and Litov (2006); Perez-Gonzalez (2006); Cremers, Nair, and Wei (2007); and Dittmar and Mahrt-Smith (2007)

2 This point was recognized by Gompers, Ishii, and Metrick (2003). To focus on examining the general question whether there is a connection between corporate governance provisions in the aggregate and firm value, they chose to abstract from assessing the relative significance of provisions by assigning an equal weight to all the IRRC provisions.
} 
between shareholders and managers set by other provisions. In this paper, we look inside the box of the IRRC provisions to identify which of them are responsible for the correlation between these provisions in the aggregate and firm value.

We begin our investigation by identifying a hypothesis for testing. In particular, we hypothesize that six provisions among the 24 provisions tracked by IRRC play a significant role in driving the documented correlation between IRRC provisions and firm valuation. We include in this list of six provisions all the provisions among the IRRC provisions that have systematically drawn substantial opposition from institutional investors voting on precatory resolutions. To confirm that focusing on these provisions is plausible, we also performed our own analysis of their consequences, as well conducted interviews with six leading M\&A practitioners.

Of the six provisions, four set constitutional limits on shareholder voting power, which is the primary power shareholders have. These four arrangements-staggered boards, limits to shareholder amendments of the bylaws, supermajority requirements for mergers, and supermajority requirements for charter amendments-limit the extent to which a majority of shareholders can impose their will on management. Two other provisions are the most wellknown and salient measures taken in preparation for a hostile offer: poison pills and golden parachute arrangements.

We construct an index, which we label the entrenchment index (E index), based on these six provisions. Each company in our database is given a score, from zero to six, based on the number of these provisions that the company has in the given year or month. We first explore whether these entrenching provisions are correlated with lower firm value as measured by Tobin's Q. We find that, controlling for the rest of the IRRC provisions, the entrenching provisions-both individually and in the aggregate-are negatively correlated with Tobin's Q. Increases in our E index are correlated, in a monotonic and economically significant way, with lower Tobin's Q values. Moreover, the provisions in the $\mathrm{E}$ index appear to be largely driving the correlation that the IRRC provisions in the aggregate have with Tobin's Q. We find no evidence that the eighteen provisions not in the E index are negatively correlated, either in the aggregate or individually, with Tobin's Q.

Of course, documenting that entrenching provisions are negatively correlated with lower firm valuation, like the earlier finding that the IRRC provisions in the aggregate are correlated 
with lower firm valuation, does not establish that the entrenching provisions, or that the IRRC provisions in general, cause lower firm valuation. The identified correlation could be at least partly the product of the tendency of managers of low value firms to adopt entrenching provisions. It is worth noting that even if the identified correlation between low Tobin's Q and high entrenchment were traceable to the tendency of low-Q firms to adopt high entrenchment levels (for some firms this occurred in the mid-1980s), it would have still been possible for entrenchment to play a key role in enabling the low-Q firms to retain their low-Q status. A high entrenchment level might protect low-Q firms from being taken over or forced to make changes that would raise their Tobin's Q. Indeed, such an effect is presumably why low-Q firms might wish to adopt and retain a high level of entrenchment. Thus, a mere serial correlation in firms' Tobin's Qs does not indicate that causality runs primarily from low Q to high entrenchment, rather than in the opposite direction.

In any event, to explore this issue, we examine how firm valuation during the last five years of our sample period is correlated with firms' entrenchment scores as of 1990. We find that, even after controlling for firm valuation in 1990, high entrenchment scores in 1990 are negatively correlated with firm valuation at the end of our sample period. In addition, in firm fixed effects regressions controlling for the unobserved time-invariant characteristics of firms, we find that increases in the E index during our sample period are associated with decreases in Tobin's Q. Although more work remains to be done on the question of causation, both of these findings are consistent with the possibility that the identified correlation between entrenchment and low Q is not fully the product of the low Q that firms adopting high entrenchment levels had in the first place.

After analyzing the relation between the E index and Tobin's Q, we explore the extent to which the six provisions in the index are responsible for the documented correlation between the IRRC provisions and reduced stockholder returns during the 1990s. We find that the entrenching provisions were correlated with a reduction in firms' stock returns both during the 1990-1999 period that Gompers, Ishii, and Metrick (2003) studied, and during the longer 1990-2003 period that we were able to study using the data we had. A strategy of buying firms with low E index scores and, simultaneously, selling short firms with high E index scores would have yielded substantial abnormal returns. To illustrate, during the 1990-2003 period, buying an equallyweighted portfolio of firms with a zero E index score and selling short an equally-weighted 
portfolio of firms with E index scores of five and six would have yielded an average annual abnormal return of approximately $7 \%$. In contrast, we do not find evidence that the eighteen IRRC provisions not in our E index are correlated with reduced stock returns during the time periods (1990-1999; 1990-2003) we study.

A finding of a correlation between governance and returns during a given period is subject to different possible interpretations [see, for example, Gompers, Ishii, and Metrick (2003) and Cremers, Nair, and John (2006)]. Our results on returns do not enable choosing among these interpretations, and they should not be taken to imply that the identified correlation between the E index and returns reflect market inefficiency or that it should be expected to continue in the future. But our return results do serve to highlight the significance that the $\mathrm{E}$ index provisions have among the larger universe of IRRC provisions.

We conclude that the six entrenching provisions in our E index largely drive the documented negative correlation that the IRRC provisions in the aggregate have with firm valuation and stockholder returns since 1990. This identification can contribute to the literature and to future work in corporate governance in several ways. First, our index can be used, and has already been widely used, by work seeking to examine the association between shareholder rights and various corporate decisions and outcomes. To the extent that the eighteen provisions in the GIM index that are not in the E index represent "noise," the E index can be useful by providing a measure of corporate governance quality that is not affected by the "noise" created by the inclusion of these provisions. Indeed, since the appearance of the discussion paper version of this paper [Bebchuk, Cohen, and Ferrell (2004)], more than 75 papers have already used our E index in their analysis. ${ }^{3}$

In addition, our work contributes by identifying a small set of provisions on which future research work, as well as private and public decision-makers, may want to focus. Knowing which provisions are responsible for the identified negative correlation between the IRRC provisions and firm performance can be useful for investigating the extent to which governance provisions affect (rather than reflect) value. In addition, to the extent that the identified correlation between the provisions in our $\mathrm{E}$ index and firm value at least partly reflects a causal relation going from entrenchment to firm value, these provisions are ones that deserve the attention of private and public decision-makers seeking to improve corporate governance.

\footnotetext{
3 See, for example, Masulis, Wang, and Xie (2007). For a list of the papers using the index, see http://www.law.harvard.edu/faculty/bebchuk/studies.shtml.
} 
Indeed, even if the correlation was fully driven by the desire of firm insiders at low-valued firms to protect themselves, it would be beneficial for researchers and decision-makers to know the provisions on which such protection efforts are concentrated.

Finally, although our investigation is limited to the universe of IRRC provisions, our findings have significant implications for those investigating other sets of governance provisions. In particular, our findings cast some doubt on the wisdom of an approach recently followed by shareholder advisory firms. Responding to the demand for measures of the quality of corporate governance, some shareholder advisory firms have developed and marketed indexes based on a massive number of governance attributes. Institutional Shareholder Services (ISS), the most influential shareholder advisory firm, has developed a governance metric based on 61 elements [see Brown and Caylor (2006)]. Governance Metric International has been even more ambitious, including more than 600 provisions in its index. The development and use of these indexes has put pressure on firms to change their governance arrangements in ways that will improve their rankings.

Our results indicate that this "kitchen sink" approach of shareholder advisory firms might be misguided. Among a large set of governance provisions, the provisions of real significance are likely to constitute only a limited and possibly small subset. As a result, an index that gives weight to many provisions that do not matter, and as a result under-weighs the provisions that do matter, is likely to provide a less accurate measure of governance quality than an index that focuses only on the latter. Furthermore, when the governance indexes of shareholder advisory firms include many provisions, firms seeking to improve their index rankings might be induced to make irrelevant or even undesirable changes and might use their improved rankings to avoid making the few small changes that do matter. Thus, institutional investors deciding which firms to include in their portfolios and which governance changes to press for would likely be better served if shareholder advisory firms were to use governance measures based on a small number of key provisions rather than attempt to count all the trees in the governance forest.

In prior work, Cremers and Nair (2005) use an index based on four of the provisions in the GIM index and show that it is negatively correlated with Tobin's Q, but they do not attempt to show either that other provisions do not matter or that each of the provisions used in their index matters (and, indeed, our results indicate that neither is the case). In another relevant prior work, Bebchuk and Cohen (2005) show that, controlling for all other IRRC provisions, staggered 
boards are negatively correlated with Tobin's Q. That paper did not identify which IRRC provisions other than staggered boards are negatively correlated with firm value, however, and thus completed only the first step in the inquiry we pursue fully in this paper. Although the literature using the GIM index is large, ours is the only effort to provide a full identification of the IRRC provisions that do and do not matter, with other work largely accepting and using our results concerning this identification.

The rest of our analysis is organized as follows. Section II provides the needed background in terms of theory and institutional detail. Section III describes the data. Section IV studies the correlation between the E index and firm value. Section V studies the correlation between this index and stock returns during the 1990-1999 and 1990-2003 periods. Section VI offers some concluding remarks.

\section{THE ENTRENCHMENT INDEX AND ITS ELEMENTS}

The definitions of the 24 corporate governance provisions tracked by the IRRC, including the six that we hypothesize matter in terms of increasing entrenchment, are summarized in the Appendix. The great majority of the IRRC provisions, and all the IRRC provisions that we hypothesize matter, are those that appear to provide incumbents at least nominally with protection from removal or the consequences of removal. We refer to such protection as “entrenchment."

Entrenchment can have adverse effects on management behavior and incentives. As first stressed by Manne (1965), such insulation might harm shareholders by weakening the disciplinary threat of removal and thereby increasing shirking, empire-building, and extraction of private benefits by incumbents. In addition, such insulation might have adverse effects on the incidence and consequences of control transactions. To be sure, entrenchment can also produce beneficial effects by reducing the extent to which the threat of a takeover distorts investments in long-term projects [Stein (1988) and Bebchuk and Stole (1993)] or by enabling managers to extract higher acquisition premia in negotiated transactions [Stulz (1988)]. For this reason, the theoretical literature on the various effects of entrenchment [see Bebchuk (2002) for a survey] does not establish that entrenchment would overall necessarily have an adverse effect on firm value, but only that hypothesizing such a relationship is theoretically defensible. 
An association between entrenchment and low firm value might also result from the greater incentive that managers of low-value firms have to obtain protection from the risk of removal or its consequences. An incentive on the part of managers of low-value firms to adopt entrenching provisions, and entrenchment in turn reducing firm value, are not mutually exclusive. Even if low-value firms have a greater tendency to adopt high entrenchment levels, the adopted entrenchment levels can reinforce or strengthen the correlation between low value and entrenchment. The high level of entrenchment might lead to further deterioration in value or at least prevent the improvement in value that might otherwise be caused by the threat or realization of a change in control.

Given the potential significance of entrenchment, we will attempt to identify a hypothesis for testing the identity of the provisions in the IRRC universe that are most responsible for, or reflective of, managerial entrenchment.

\section{A. The provisions garnering significant shareholder opposition}

In forming a hypothesis about which governance provisions are of significance, examining the preferences registered by institutional investors (and other shareholders) in votes on precatory resolutions seems to be an objective and natural approach. To be sure, shareholders might be mistaken in their judgment of which provisions deserve attention and opposition. But to the extent that shareholders have focused their attention and opposition on some provisions and not others, their views can help inform the inquiry as to which IRRC provisions should be deemed to be potentially significant.

To this end, we reviewed the data reported by Georgeson Shareholder, the leading proxy solicitation firm, in its ANNUAL CoRPorate Governance REVIEW concerning the incidence and outcomes of shareholder precatory resolutions at the end of our sample period (the end of 2003). ${ }^{4}$ At this point in time, shareholders' voting decisions could have been informed by whatever shareholders might have learned during the sample period or earlier. Given that the end of the sample period falls between the 2003 and 2004 proxy seasons, we examined the data gathered by Georgeson Shareholder with respect to shareholder votes on precatory resolutions

\footnotetext{
${ }^{4}$ Georgeson Shareholder did not track shareholder votes on precatory resolutions at the beginning of our sample period.
} 
during both the 2003 proxy season [Georgeson Shareholder (2003)] and the 2004 proxy season [Georgeson Shareholder (2004)].

The question we investigated in examining the incidence and outcomes of shareholder precatory resolutions was which of the 24 IRRC provisions were opposed by a non-trivial number of precatory resolutions that often passed. An examination of the data indicates four types of precatory resolutions, targeting six IRRC provisions, stood out. Each of these types of precatory resolutions was submitted a significant number of times (15 or more times during the 2003-2004 proxy seasons) and passed (obtaining a majority of the votes cast by shareholders) in a majority of the cases in which it was submitted. The four types of precatory resolutions, and the six IRRC provisions they targeted, were as follows:

- Resolutions against classified boards, which passed in $91 \%$ of the votes on them during 2003-2004;

- Resolutions against poison pills, which passed in $72 \%$ of the votes on them during 20032004;

- Resolutions against golden parachutes, which passed in $62 \%$ of the votes on them during 2003-2004; and

- Resolutions against supermajority provisions, which simultaneously targeted supermajority merger requirements, limits on charter amendments, and limits on bylaw amendments, which passed in $100 \%$ of the votes on them during 2003-2004. (The Georgeson data reports one figure for all resolutions against supermajority provisions, reflecting the fact that precatory resolutions targeting supermajority provisions generally express support for a general simple-majority standard and opposition to all types of supermajority voting requirements.)

All the other 18 IRRC provisions do not come even close to the above six IRRC provisions in terms of being the target of a significant number of opposing resolutions obtaining majority support among shareholders. To begin, out of these 18 provisions, 17 were the subject of either no or only a de minimis number of precatory resolutions (let alone passing resolutions): 13 provisions were not the target of even a single precatory resolution during the 2003 and 2004 proxy seasons; ${ }^{5}$ and 4 provisions had only a nominal presence in the precatory resolution

\footnotetext{
${ }^{5}$ These IRRC provisions are: director indemnification, director indemnification contract, limited director liability, compensation plan, severance agreement, unequal voting rights, blank check preferred stock, fair price requirements, cash-out law, director duties, antigreenmail, pension parachute, and silver parachute.
} 
landscape, with none of them targeted by more than three precatory resolutions over the entire 2003-2004 period. ${ }^{6}$ Finally, out of the 18 provisions, only one of them-absence of cumulative voting-was the target of a significant number of precatory resolutions, but these resolutions commonly failed to pass. The resolutions, most of which were initiated by the same individual who submitted the same resolutions at many companies, passed in a mere $7 \%$ of the cases in which votes on them were held.

\section{B. Discussion of the provisions in the E index}

Having identified the subset of IRRC provisions that attracted substantial shareholder opposition, we also undertook our own legal and economic analysis of the possible significance of each of these six provisions. In conducting this analysis, we were informed and assisted by interviews we conducted with six highly prominent M\&A practitioners in six major corporate law firms. ${ }^{7}$ The purpose of our analysis was to provide a cross-check to ensure that we were not proceeding to the testing stage with a provision whose inclusion in our index would be implausible based on such an analysis.

The six provisions in the E index can be divided into two categories. Four of them involve constitutional limitations on shareholders' voting power. The other two provisions can be regarded as "takeover readiness" provisions that boards sometimes put in place. Below we discuss the reasons for viewing their inclusion in our $\mathrm{E}$ index as plausible. Before proceeding, it is worth stressing that the point of the discussion below is not that the analysis proves that each of the provisions must be correlated with lower firm value. Indeed, if that were the case, there would be little need for empirical testing. Rather, the issue is whether there are reasons to view shareholders' focus on and opposition to these six provisions, as evidenced by shareholders'

\footnotetext{
${ }^{6}$ These four IRRC provisions were special meeting, written consent, opt-out of state takeover law, and confidential voting.

${ }^{7}$ These lawyers were: Richard Climan, head of the mergers \& acquisitions group at Cooley, Godward; David Katz, a senior corporate lawyer at Wachtell, Lipton, Rosen \& Katz; Eileen Nugent, a co-author of a leading treatise on acquisitions and a senior corporate lawyer at Skadden, Arps, Sale, Meagher \& Flom; Victor Lewkow, a leading mergers \& acquisitions lawyer at Cleary Gottlieb; James Morphy, managing partner of the mergers and acquisitions group at Sullivan \& Cromwell; and Charles Nathan, global cochair of the mergers and acquisitions department of Latham \&Watkins. We are grateful to them for their time and insights.
} 
votes on precatory resolutions, as sufficiently plausible to justify inclusion of these six provisions in an $\mathrm{E}$ index of provisions whose significance will then be the subject of empirical testing.

\section{Constitutional limitations on shareholders' voting power}

At bottom, shareholders' most important source of power is their voting power [Clark (1986)]. But shareholders' voting power can be constrained by constitutional arrangements that constrain the ability of a majority of the shareholders to have their way.

When the firm has a staggered board, directors are divided into classes, almost always three, with only one class of directors coming up for reelection each year. As a result, shareholders cannot replace a majority of the directors in any given year, no matter how widespread the support among shareholders for such a change in control. This makes staggered boards a powerful defense against removal in either a proxy fight or proxy contests. There is evidence that staggered boards are a key determinant for whether a target receiving a hostile bid will remain independent [Bebchuk, Coates, and Subramanian (2002, 2003)]. The lawyers we interviewed were all of the view that staggered boards are a key defense against control challenges.

There is also evidence that, controlling for all the other IRRC provisions, staggered boards are negatively correlated with Tobin's Q [Bebchuk and Cohen (2005)]. Furthermore, there is evidence that firms' announcement of a classified board adoption are accompanied with negative abnormal stock returns [Faleye (2007)] and that firms' announcements that they are going to dismantle their staggered board are accompanied by positive abnormal stock returns [Guo, Kruse, and Nohel (2008)]. To be sure, some researchers and market participants maintain that investors' concerns about staggered boards are exaggerated or even unwarranted [Wilcox (2002) and Bates, Becher, and Lemmon (2008)]. But there is little reason to doubt that the hypothesis that staggered boards play a significant role in driving the correlation between the IRRC provisions and firm value is one that would be reasonable to subject to empirical testing.

In addition to the power to vote to remove directors, shareholders have the power to vote on bylaw amendments, charter amendments, and mergers. Three types of IRRC provisions make it more difficult for the majority of shareholders to have their way on such important issues: limits on by-law amendments, which usually take the form of supermajority requirements; supermajority requirements for mergers; and supermajority provisions for charter amendments. 
As noted earlier, shareholders have registered strong opposition to such provisions. One hundred percent of the resolutions opposing such supermajority provisions during the 2003 and 2004 proxy season passed, attracting on average $67 \%$ of the shares cast [Georgeson Shareholder (2003, 2004)]

The M\&A lawyers we interviewed were all in consensus that limits on bylaw amendments can significantly enhance the effectiveness of a target's defenses. A well-known Delaware case, Chesapeake Corp. v. Marc P. Shore, also expressed this view; the court in this case ruled that a supermajority requirement of two-thirds of all outstanding shares for a bylaw amendment had draconian antitakeover consequences, making it practically impossible for non-management shareholders to remove defensive provisions that management earlier placed in the bylaws.

As to supermajority requirements for mergers and charter amendments, these provisions can provide (and are so viewed by the M\&A lawyers we interviewed) "a second line of defense" against a takeover. When such provisions are present, insiders holding a block of shares might be in a position to defeat or impede charter amendments or mergers even if they lose control of the board. Thus, to the extent that such provisions could enable management and shareholders affiliated with them to frustrate the plans of a buyer of a control block, this might discourage hostile buyers from seeking to acquire such a block in the first place.

\section{Takeover readiness provisions}

Poison pills (less colorfully known as shareholder rights plans) are rights that, once issued by the company, preclude a hostile bidder as a practical matter from buying shares as long as the incumbents remain in office and refuse to redeem the pill. The legal developments that allowed boards to put in place pills are thus widely regarded to have considerably strengthened the protections against replacement that incumbents have.

During the period of examination, shareholder resolutions seeking to limit poison pills constituted a significant fraction of all shareholder resolutions, and these resolutions attracted substantial shareholder support. At the end of the period, resolutions calling for limitations on the use of the poison pill obtained an average of $60 \%$ of votes cast with a passage rate of $72 \%$. [Georgeson Shareholder $(2003,2004)]$ 
It should be noted that boards may adopt poison pills, with no need for a shareholder vote of approval, not only before but also after the emergence of a hostile bid. For this reason, companies without a poison pill in place can still be viewed as having a "shadow pill" that could be rolled out in the event of a hostile bid [Coates (2000)]. Nonetheless, during the period under examination, a substantial fraction of companies (ranging from $54 \%$ to $59 \%$ during the period) do have pills in place.

Having a poison pill in place is not costless for the board because institutional investors look unfavorably on poison pills and a board could "get points" with such investors by not having a pill. Thus, boards and their advisers maintaining a pill were presumably led to do so by a belief that it would provide them with some advantages. The leading M\&A lawyers we interviewed noted several reasons why they and other lawyers often advised clients concerned about a hostile bid to put a pill in place. To begin, having a pill in place provides an absolute barrier to any attempts by outsiders to obtain through market purchases a block larger than the one specified by the terms of the pill (usually 10\%-15\%). ${ }^{8}$ In addition, having the pill in place saves the need to install it in "the heat of battle." This removes one issue from those that the board and its independent directors will have to deal with should a hostile bid be made. Furthermore, according to the lawyers we interviewed, there was a widespread perception that maintaining a pill signals to hostile bidders that the board will "not go easy" if an unsolicited offer is made and that, conversely, not adopting a pill or (even worse) dropping an existing pill could be interpreted as a message that incumbents are "soft" and "lack resolve." For all these reasons, incumbents worried about a hostile bid could have slept somewhat better by putting a pill in place prior to a hostile bid being made. ${ }^{9}$

Golden parachutes are terms in executive compensation agreements that provide executives who are fired or demoted with substantial monetary benefits in the event of a change in control. Golden parachutes protect incumbents from the prospect of replacement by providing

\footnotetext{
${ }^{8}$ Incumbents have some protection from attempts to obtain quickly a significant block by the notice requirements of the Hart-Scott-Rodino Act and the Williams Act. But as John Malone's surprise move to increase his stake at News Corp illustrates, a poison pill (which News Corporation's management hastily adopted) is sometimes necessary to block such moves.

${ }^{9}$ Some early studies examined how the adoption of a poison pill affected the firm's stock price [see, for example, Ryngaert (1988)]. When a firm adopts a poison pill, however, its stock price might be influenced not only by the expected effect of the poison pill but also by inferences that investors make as to management's private information about the likelihood of a bid [Coates (2000)].
} 
management with a soft and sweet landing in the event of ouster. Thus, a golden parachute provides incumbents with substantial insulation from the economic costs that they would otherwise bear as a result of losing their control.

To be sure, golden parachutes may also produce benefits for shareholders by making incumbents more willing to accept an acquisition and increasing the likelihood of an acquisition [Lambert and Larker (1985), Bebchuk, Cohen, and Wang (2008)]. However, while this effect might be beneficial, golden parachutes might also have an adverse effect by increasing slack on the part of managers as a result of being less subject to discipline by the market for corporate control. Whether the latter effect outweighs the former is an empirical question. It is also possible that golden parachutes may be negatively correlated with firm value to the extent that managers of low-value firms who face a higher likelihood of being acquired are especially likely to seek them [Bebchuk, Cohen, and Wang (2008)]. According to the M\&A lawyers we interviewed, they recommend golden parachutes to any incumbents who attach a significant likelihood of their company being acquired. ${ }^{10}$

We decided to include golden parachutes in the E index based on their potential insulating effects for management and the substantial shareholder support for limiting their use during the period of our study. At the end of this period, resolutions targeting golden parachutes received on average $51 \%$ of votes cast with a passage rate of 62\% [Georgeson Shareholder $(2003,2004)]$.

It is worth stressing that golden parachutes, as that variable is defined by the IRRC, are quite different from three other IRRC provisions: severance agreements, compensation plans, and silver parachutes. Severance contract payments, as defined by the IRRC, are not conditional on the occurrence of a change in control. Silver parachutes provide benefits to a large number of the firm's employees and do not target the firm's top executives, whose insulation from a control contest could matter most in terms of increasing managerial slack. Compensation plans are plans that accelerate benefits, such as option vesting, but do not by themselves provide additional benefits in the event of a change in control, in contrast to golden parachutes. These differences might explain why shareholder precatory resolutions have targeted golden parachutes rather than any of these three other IRRC provisions.

${ }^{10}$ To be sure, even when executives do not have a golden parachute in their ex ante compensation contracts, boards can and often do grant executives "golden good-bye" payments when an acquisition offer is already on the table [Bebchuk and Fried (2004, Ch. 7)]. But such ex post grants require much more explaining to outsiders. 


\section{Discussion of the other provisions}

We now discuss the 18 provisions not in the $\mathrm{E}$ index. We do not include them in the index because, as explained in subsection II.A, none of these provisions is the target of frequent and commonly successful shareholder resolutions. As we did in connection with the provisions included in the E index, we also conducted our own analysis, based in part on the existing literature and on our interviews with prominent practitioners. This analysis was intended to serve as a cross-check, namely, to examine whether there are any provisions which, notwithstanding the described record of shareholder voting, are so clearly important that proceeding to test the hypothesis that the provisions in the $\mathrm{E}$ index are those most likely to matter is a priori implausible.

Our analysis of these eighteen provisions did not reveal a basis for viewing any of them as those that are bound to be significant. Indeed, with respect to most of these provisions, our analysis suggested reasons to expect them to be inconsequential. For example, some antitakeover statutes, fair price provisions, and business combination statutes, constituted takeover protections that were important in the late 1980s but subsequently became largely irrelevant due to legal developments that provide incumbents with the power to use more powerful takeover defenses. ${ }^{11}$

Another takeover-related provision that we believe to be largely inconsequential is blank check preferred stock. This provision was included by the IRRC and prior research in the set of studied provisions because blank check preferred stock is the currency most often used for the creation of poison pills. However, lawyers are able to, and do, create poison pills without blank check preferred stock. Indeed, in the IRRC data, of the companies that did not have a blank check preferred stock in 2002, about $45 \%$ nevertheless had a poison pill in place.

\footnotetext{
${ }^{11}$ As long as incumbents are in office, they can now use a poison pill to prevent a bid and thus have little need for the impediments provided by most antitakeover statutes. And if the bidder were to succeed in replacing incumbents with a team that would redeem the pill, these impediments would be irrelevant because they apply only to acquisitions not approved by the board. Our legal analysis of these provisions was echoed in our interviews with the leading M\&A lawyers mentioned earlier. It is worth noting that studies identifying some effects of antitakeover statutes on firms largely focused on data from an earlier period during most of which such statutes did plausibly matter because incumbents did not yet have the power to maintain poison pills indefinitely [see, for example, Borokohovich, Brunarski, and Parrino (1997); Johnson and Rao (1997); Bertrand and Mullainathan (1999); Garvey and Hanka (1999); and Bertrand and Mullainathan (2003)]
} 
Similarly, there is evidence that limits on special meeting and written consent do not have a statistically significant effect on the outcome of hostile bids [Bebchuk, Coates, and Subramanian (2003)]. Such limits prevent shareholders from voting between annual meetings and require them to wait until the annual meeting to conduct any vote, but the practical significance of the required delay is limited. Even when shareholders can act by written consent or call a special meeting, the rules governing proxy solicitations are likely to impose some delay before a vote can be conducted. And waiting until the next annual meeting commonly does not involve substantial delay. Perhaps not surprisingly, limitations on special meeting and written consent are virtually never the subject of a precatory resolution [Georgeson Shareholder (2003, 2004)].

Some of the IRRC provisions are related not to issues of control changes but rather to issues of liability and indemnification in the event of shareholder suits. As Black, Cheffins, and Klausner (2006) powerfully argue and document, directors are protected from personal liability by myriad factors. The risk of liability is negligible even in companies that do not have any of the IRRC provisions. Personal liability might arise in some rare cases of egregious bad faith behavior, but in such cases the three liability and indemnification provisions in the IRRC set would provide no protection.

Finally, with respect to a few of the provisions not in the E index, an analysis cannot establish unambiguously that they are bound to be insignificant. However, given the absence of a solid basis for expecting these other provisions to be significant, our approach was to proceed with the hypothesis developed on the basis of the evidence concerning shareholder voting to test whether the six provisions in the E index are those that matter. As will be explained below, in conducting our testing, we remained open to and explored the possibility that one or more of the provisions not in our $\mathrm{E}$ index also play a significant role in producing the correlation between the IRRC provisions in the aggregate and firm value.

\section{The E index and the other provisions index}

Based on the above discussion, we construct two indexes. As is standard in the literature constructing governance indices on the basis of a set of provisions [La Porta, Lopez-de-Silanes, and Shleifer (1998) and Gompers, Ishii, and Metrick (2003)], each of our indexes gives an equal weight to each of the provisions in the set. Of course, as is generally recognized in this literature, 
some relevant provisions could deserve more weight than others, and the appropriate weight of a provision might depend on the presence or absence of other provisions (that is, interactions could matter), and the standard equal-weight construction is an approach that we, like others in the literature, use for its simplicity. Our effort focuses on extending the literature by narrowing the set of relevant provisions while continuing to use the standard approach for constructing an index on the basis of this relevant set.

Thus, the level of the "entrenchment index" for any given firm is calculated by giving one point for each of the six components of the index that the firm has. The "other provisions index" (O index) is based on all the other 18 provisions not included in the E index and tracked by the IRRC. This index, like the E index, counts all the provisions included in it equally, giving one point for each one of these provisions a firm has. The conjecture to be tested is that our E index drives to a substantial degree the correlation identified in earlier research between the IRRC provisions, in the aggregate, and firm valuation.

\section{DATA AND SUMMARY STATISTICS}

\section{A. Data sources}

Our data set includes all the companies for which there was information in one of the volumes published by the Investor Responsibility Research Center (IRRC). The IRRC volumes include detailed information on the corporate governance arrangements of firms. The IRRC has published six such volumes: September, 1990; July, 1993; July, 1995; February, 1998; November, 1999; and February, 2002.

Each volume includes information on between 1,400 and 1,800 firms, with some variation in the list of included firms from volume to volume. All the firms in the S\&P 500 are covered in each of the IRRC volumes. In addition, a number of firms not included in the S\&P 500 but considered important by the IRRC are also covered. In any given year of publication, the firms in the IRRC volume accounted for more than $90 \%$ of the total U.S. stock market capitalization.

Because the IRRC did not publish volumes in each year, we assumed, following Gompers, Ishii, and Metrick (2003), that firms' governance provisions as reported in a given IRRC volume were in place during the period immediately following the publication of the volume until the 
publication of the subsequent IRRC volume. Using a different "filling" method, however, does not change our results.

In addition to the IRRC volumes, we also relied on Compustat, CRSP, and ExecuComp. Firm financials were taken from Compustat. Stock return data was taken from the CRSP monthly datafiles. Insider ownership data was taken from ExecuComp. The age of firms, following Gompers, Ishii, and Metric (2003), was estimated based on the date on which pricing information about a firm first appeared in CRSP.

In calculating abnormal returns, we used the three Fama-French benchmark factors, which were obtained from Kenneth French's website. The Carhart momentum factor was calculated by us using the procedures described in Carhart (1997) using information obtained from CRSP.

We excluded firms with a dual class structure. In these companies the holding of superior voting rights might be sufficient to provide incumbents with a powerful entrenching mechanism that renders other entrenching provisions relatively unimportant. We also excluded real estate investment trusts (REITs), i.e., firms with a SIC Code of 6798, as REITs have their own special governance structure and entrenching devices. While we kept both financial and nonfinancial firms in our data, running our regressions on a subset consisting only of nonfinancial firms [as done by Daines (2001)] yields similar results throughout.

\section{B. Summary statistics}

Table 1 provides summary statistics about the incidence of the 24 IRRC governance provisions, including the six provisions we have chosen to include in our E index, during the period covered by our study. ${ }^{12}$

\footnotetext{
${ }^{12}$ We use, throughout, the definitions of the IRRC provisions used by Gompers, Ishii, and Metrick (2003). For example, because the IRRC used in some years the term secret ballot and in some years the term confidential voting to describe essentially the same arrangement, GIM defined a company as having no secret ballot in a given year when it did not have in that year in the IRRC dataset either the secret ballot variable or the confidential voting variable. To give another example, GIM defined a company as having a fair price arrangement in a given year when in that year it (1) had the variable for a fair price charter provision, or (2) had the variable indicating incorporation in a state with a fair price provision and (3) did not have the variable indicating a charter provision opting out of the state's statute. We are grateful to Andrew Metrick for providing us with the GIM set of definitions of the 24 IRRC provisions.
} 
Of the six provisions in the E index, staggered boards, golden parachutes, and poison pills are the most common, with each present in a majority of companies. The incidence of golden parachutes has been increasing steadily, starting at 53\% as of 1990 and reaching approximately $70 \%$ in 2002. The incidence of staggered boards has been stable at around $60 \%$, and the incidence of poison pills has been relatively stable as well, in the 55\%-60\% range.

The incidence of supermajority provisions has been declining slightly over time, starting at 39\% in 1990 and ending at approximately 32\% in 2002. The incidence of limits to bylaws has been increasing, starting at $14.5 \%$ in 1990 and reaching approximately 23\% by 2002. Of the six provisions, the only one that does not have a substantial presence are provisions that limit charter amendments, which has throughout the 1990-2002 period a very low incidence hovering around $3 \%$.

The E index assigns each company one point for each of the six provisions in the index that the firm has. Accordingly, each firm in each year will have an E index score between zero and six. Table 2 provides summary statistics about the incidence of the index levels during the study period. On the whole, there was a moderate upward trend in the levels of the E index during this period. While $55 \%$ of the firms had an index level below three in 1990 , only $49 \%$ of the firms were in this range in 2002. Especially significant was the decline in the incidence of firms with a zero entrenchment level, from 13\% in 1990 to approximately 7\% in 2002.

As for the cross-sectional distribution of firms across entrenchment levels, roughly half of the companies have an entrenchment level of three or more, while roughly half have an entrenchment level below three. Of the half of the firms with entrenchment levels below three, a substantial fraction are at two, with firms at the zero and one levels constituting $23 \%$-31\% of all firms. For the roughly half of the firms with entrenchment levels of three or more, a substantial fraction are at three, with firms in the four to six range constituting 19\%-23\% of all firms.

A relatively small fraction of firms are at the extremes. Given that one of the provisions is present in only about $3 \%$ of firms, it is not surprising that only a few firms reach the maximum level of six, with its incidence never exceeding $0.7 \%$ of the sample. Given the small number of observations with E index scores of six, firms in index level six are grouped together with firms in index group five in the course of conducting the statistical analysis. This group of companies with index scores of five and six, the very worst companies in terms of their entrenchment scores, constitute approximately 3.5\%-5\% of all firms throughout the period. At the other end of 
the spectrum, the group of companies that are the "best" in terms of entrenchment are those firms with a zero entrenchment level. These firms constitute roughly 7\%-13\% of all firms during the 1990-2002 period.

The correlation between the E index and the GIM index is 0.74 , while the correlation between the $\mathrm{O}$ index and the GIM index is 0.89 . The $\mathrm{E}$ index and the $\mathrm{O}$ index, however, have a correlation of only 0.36 with each other. Because the $\mathrm{E}$ index and the $\mathrm{O}$ index are both significant elements of the GIM index, and because the $\mathrm{O}$ index contributes three times more provisions to the GIM index than the E index, it is not surprising that both sub-indexes are substantially correlated with the GIM index, and that the O index has a higher correlation. Note that, because the $\mathrm{O}$ index contributes many provisions to the GIM index and has a correlation of only 0.36 with the E index, the E index and the GIM index fall significantly short of being perfectly correlated. If the provisions in the $\mathrm{E}$ index are indeed those that matter for correlation with firm value, then the addition of the other provision index to the $\mathrm{E}$ index to form the GIM index is adding a significant amount of "noise."

Turning to the correlation of the six entrenching provisions, the correlation tends to be relatively low. Nine out of the 15 correlations are less than 0.1 . The highest correlation of 0.31 is that between poison pills and golden parachutes, our two "takeover readiness" provisions. The second highest correlation, at 0.24 , is that between limits on ability of shareholders to amend the corporate bylaws and limits on shareholders' ability to amend the corporate charter. The relatively low correlation among the entrenching provisions suggests that each entrenching provision is potentially a candidate for inclusion in the $\mathrm{E}$ index as a stand-alone element, rather than merely on the basis of being highly correlated with some other entrenching provision.

There are no significant differences between firms in and out of the S\&P 500 in terms of their entrenchment scores (respectively 2.58 and 2.46), and there are likewise no noteworthy entrenchment score differences between young and old firms (2.30, 2.35, and 2.82 for, respectively, the 1990s, 1980s, and pre-1980). It is worth noting, however, that entrenchment levels are different in firms that are very large in size. In 2002, out of the 15 companies with a market cap exceeding $\$ 100$ billion, only one had an E level index exceeding three. This is not surprising. With no hostile bid or proxy fight ever directed at a company of this size, the managements of these very large firms have no need for entrenching provisions in order to be secure. 
Table 3 provides the distribution of the $\mathrm{O}$ index for the IRRC publication years. As Table 3 indicates, the highest level of the $\mathrm{O}$ index actually reached by firms is 13; and the lowest level of the $\mathrm{O}$ index that firms actually have is one. Approximately $40 \%-45 \%$ of firms have an $\mathrm{O}$ index score of six or less, with the remaining firms having an $\mathrm{O}$ index score of seven or more. There are very few firms at the extremes, with only roughly $1 \%$ of firms having an $\mathrm{O}$ index score of one or two and another $1 \%$ of firms having an $\mathrm{O}$ index score of 12 or 13 . The correlation between the $\mathrm{O}$ index and the $\mathrm{E}$ index ranges from 0.3 to 0.35 throughout the 1990-2002 period. Thus, to the extent that the provisions in the $\mathrm{E}$ index matter but those in the $\mathrm{O}$ index do not, including the latter in the governance measure could contribute a significant amount of noise.

\section{ENTRENCHMENT AND FiRM VALUE}

In studying the association between the E index and firm value, we use Tobin's $\mathrm{Q}$ as the measure of firm value. In doing so, we follow Gompers, Ishii, and Metrick (2003), as well as earlier work on the association between corporate arrangements and firm value [see, for example, Demsetz and Lehn (1985); Morck, Shleifer and Vishny (1988); McConnell and Servaes (1990); Lang and Stulz (1994); Daines (2001); La Porta, Lopez-de-Silanes, Shleifer, and Vishny (2002)].

We use the definition of Tobin's Q that was used by Kaplan and Zingales (1997) and subsequently also by Gompers, Ishii, and Metrick (2003). According to this specification, Q is equal to the market value of assets divided by the book value of assets, where the market value of assets is computed as the book value of assets plus the market value of common stock less the sum of book value of common stock and balance sheet deferred taxes. This measure (and simpler ones that drop deferred taxes) have been increasingly used in light of the complexities involved in the more sophisticated measures of Q and the evidence of very high correlation between this proxy and more sophisticated measures [see, for example, Chung and Pruitt (1994)].

Our dependent variable in most regressions is the log of industry-adjusted Tobin's Q, where industry-adjusted Tobin's $\mathrm{Q}$ is a firm's $\mathrm{Q}$ minus the median $\mathrm{Q}$ in the firm's industry in the observation year. We defined a firm's industry by the firm's two-digit primary SIC Code. Using the Fama-French (1997) classification of 48 industry groups, rather than SIC two-digit Codes, 
yields similar results. Using industry-adjusted Tobin's Q as the dependent variable also produces similar results.

As independent variables, we use throughout standard financial controls. These controls include the assets of the firm (in logs), the age of the firm (in logs) [Shin and Stulz (2000)], and whether the firm is incorporated in Delaware—all variables used by Gompers, Ishii, and Metrick (2003). We also use additional controls that the literature has used in Q regressions - the level of insider ownership, return on assets, capital expenditures on assets, research and development expenditures, and leverage. (Using only the controls used by Gompers, Ishii, and Metrick (2003) produces similar results throughout.) Moreover, we use dummies for firms' two-digit SIC Codes. In all of the regressions, in addition to the standard financial and ownership controls, we controlled for firms' O index scores in order to control for the IRRC provisions not included in the E index. In our Q-regressions, we focus on the period 1992-2002, because our inside ownership data (from ExecuComp) did not cover 1990, 1991, and 2003.

\section{A. The $E$ index and the $O$ index}

\section{A first look}

Table 4 presents the results of pooled OLS regressions for the 1992-2002 period. The pooled OLS regressions in Table 4 used White (1980) robust standard errors to account for potential heteroskedasticity. In the first column of Table 4, we used as an independent variable, in addition to the financial variables and $\mathrm{O}$ index discussed above, firms' $\mathrm{E}$ index scores. As Column 1 indicates, the coefficient on the $\mathrm{E}$ index is negative (with a value of -0.044) and statistically significant at the $1 \%$ level. The coefficient of the $\mathrm{O}$ index is also significant at the $1 \%$ level, but it is positive (with a value of 0.01 ).

In the second column, in order to avoid the imposition of linearity on the E index, we used dummy variables to stand for the different levels that the index can take. As the results indicate, the coefficient for any level of the index above zero is negative, with all being significant at the 1\% level (except for the Entrenchment Index 4 dummy which is significant at the 5\% level). Moreover, the magnitude of the coefficient is monotonically increasing in the level of the $\mathrm{E}$ index. 
To avoid imposition of linearity on the $\mathrm{O}$ index, we also ran unreported regressions using the log of the $\mathrm{O}$ index as a control, and obtained similar results to those reported in Table 4. In unreported regressions, we also ran regressions using industry-adjusted $Q$ as the dependent variable instead of its log, and obtained similar results. Finally, we ran median regressions and, again, obtained similar results.

\section{Controlling for unobserved firm characteristics}

We next ran regressions using firm fixed effects in order to control for unobserved firm heterogeneity that remains constant over the time period we study. The fixed effects regressions, reported in Columns 3 and 4 of Table 4, examine the effect on firm value of changes that firms made, during the 1990-2003 period, in the number of entrenching provisions (whether to increase or decrease the number of entrenching provisions). As Table 1 indicates, there was meaningful variation in the incidence of some entrenching provisions over the 1990-2003 period, such as golden parachutes and limits on shareholders' ability to amend bylaws, that would result in changes in firms' entrenchment scores. Other entrenching provisions, and in particular staggered boards, were rarely changed by firms during the period of study, and are therefore unlikely to constitute a significant source for changes in firms’ entrenchment scores.

As Columns 3 and 4 indicate, in the firm fixed effects regressions, the coefficient values for

the E index (Column 3) and the coefficient values for the dummy variables for the different levels of the E index above zero (Column 4) remain negative, economically meaningfully, and statistically significant at the $1 \%$ level (except for the coefficient value on having an entrenchment level of one where the statistical significance is $5 \%$ ). The magnitudes of the coefficient values also continue to increase monotonically in the level of the $\mathrm{E}$ index. The coefficient value on the $\mathrm{O}$ index remains positive, but is no longer statistically significant.

\section{Annual regressions}

For a final robustness check, we also ran annual regressions. In all regressions, we used the E index and the $\mathrm{O}$ index as the independent governance variables. We first ran a set of annual regressions similar to the baseline regressions in Column 1 of Table 4, with OLS regressions 
employing the log of industry-adjusted $Q$ as the dependent variable. We then also ran a set of median regressions with log of industry-adjusted Q as the dependent variable, as well as a set of OLS regressions with industry-adjusted $Q$ as the dependent variable. We calculated the FamaMcBeth coefficients for each set of annual regressions.

Table 5 displays the results of these three sets of annual regressions, displaying only the coefficients of the $\mathrm{E}$ index and of the $\mathrm{O}$ index. The coefficient of the $\mathrm{E}$ index is negative in all of the individual annual regressions. Of the 33 estimated negative annual coefficient values on the E index (three sets of annual regressions per year times 11 years), 27 were statistically significant. Of the six negative coefficient values without significance, three occurred in one year (1992). The Fama-McBeth coefficient value on the E index is negative at the $1 \%$ level for each one of the three sets of annual regressions.

As for the $\mathrm{O}$ index, the coefficient on the $\mathrm{O}$ index in the annual regressions is positive in a substantial majority of the annual regressions, and occasionally positive with statistical significance. It is never negative and statistically significant in any of the annual regressions. The Fama-McBeth coefficient value on the $\mathrm{O}$ index is positive at the $1 \%$ level in each one of the three sets of annual regressions, albeit with a coefficient with a small magnitude.

\section{B. Individual provisions: looking inside the two indexes}

The analysis in Section IV.A indicates that the six entrenching provisions we have identified are, in the aggregate, highly correlated with lower firm valuation. There is still the possibility, however, that one or more of the individual entrenching provisions are not contributing to this negative effect on firm valuation. To explore this possibility, we ran several sets of regressions whose results are displayed in Table 6.

In the first set of six regressions, we ran a regression for each of the six provisions in the $\mathrm{E}$ index in which the independent corporate governance variables were (i) one of the six entrenching provisions, and (ii) the GIM index minus the entrenching provision in (i). That is, each of the regressions has one of the entrenching provisions as an independent variable while 
controlling for all the other IRRC provisions. The financial controls used earlier (see Table 4 regressions) are also used as independent variables. ${ }^{13}$

The results of these six regressions, one for each of the entrenching provisions, are displayed in row one of Table 6. In each of the regressions, the coefficient of the entrenching provision under investigation is negative and statistically significant. Five entrenching provisions have statistically significant negative coefficient values at the $1 \%$ level, while the other one has statistical significance at the $5 \%$ significance.

It is worth cautioning that not too much should be read into the differences in the levels of statistical significance and coefficient estimates of the various entrenching provisions due to the problem of co-linearity. Each entrenching provision is positively correlated with the GIM index minus that entrenching provision. Accordingly, it might well be that any particular entrenching provision's coefficient is underestimated. The one conclusion that can be comfortably drawn from the results displayed in row one of Table 6 is that each of the entrenching provisions contributes to the negative correlation between Tobin's Q and the IRRC provisions in the aggregate.

For a robustness check, we then proceeded to run three additional sets of regressions. In particular, we ran for each entrenching provision i the following types of regressions:

(1) A regression in which the independent corporate governance variables in addition to entrenching provision $\mathrm{i}$ are (a) a variable equal to the $\mathrm{E}$ index minus provision $\mathrm{i}$, and (b) the $\mathrm{O}$ index.

(2) A regression in which the independent corporate governance variables in addition to entrenching provision i are (a) dummy variables for each of the five other entrenching provisions, and (b) the $\mathrm{O}$ index.

(3) A regression in which the independent corporate governance variables in addition to entrenching provision i are dummy variables for each of the other 23 IRRC provisions.

Rows 2, 3, and 4 of Table 6 display the results of the regressions of type (1), (2), and (3) respectively. For each one of the six entrenching provisions, the coefficient in each of the three types of regressions was negative and statistically significant at $1 \%$ or $5 \%$. Thus, none of our

\footnotetext{
${ }^{13}$ We display only the coefficients of the entrenching provision being investigated in each regression. In all the regressions, the coefficient of the GIM index minus the provision under investigation is negative and significant, and the coefficients of the financial controls are similar to those obtained in earlier regressions.
} 
robustness tests provide any evidence that is inconsistent with the view that each of the six entrenching provisions contributes to the negative correlation that the IRRC provisions in the aggregate have with Tobin's Q.

We now turn to the 18 provisions in the $\mathrm{O}$ index. The results reported earlier indicate that, in the aggregate, these 18 provisions are not negatively correlated with firm valuation. This finding does not imply, however, that none of the 18 provisions contained in this index is harmful for firm valuation. It might be that one or more provisions have adverse effects, but this effect does not show up in our regressions because it is diluted or counteracted by the effects of the provisions contained in the $\mathrm{O}$ index. Indeed, the results of our paper highlight the importance of looking inside the "box" of a broad index to try to identify the effects of particular corporate governance provisions.

Accordingly, we carried out a preliminary investigation to look inside the $\mathrm{O}$ index. We ran four sets of 18 regressions (for 72 regressions overall) whose results are displayed in Table 7. In particular, for each provision $\mathrm{i}$ in the $\mathrm{O}$ index, we ran the following four types of regressions:

(1) A regression in which the independent corporate governance variables were provision i, and a variable equal to the GIM index minus provision $\mathrm{i}$;

(2) A regression in which the independent corporate governance variables were provision i, a variable equal to the $\mathrm{O}$ index minus provision $\mathrm{i}$, and the $\mathrm{E}$ index;

(3) A regression in which the independent corporate governance variables were provision i, dummies for each of the other 17 provisions in the $\mathrm{O}$ index, and the $\mathrm{E}$ index; and

(4) A regression in which the independent corporate governance variables were provision i and dummies for each of the other 23 IRRC provisions.

Rows 1, 2, 3, and 4 of Table 7 display the results of the regressions of type (1), (2), (3), and (4) respectively (only the coefficient of the provision under investigation in any given regression is displayed). The standard financial controls used in earlier regressions were also used in these regressions (see regressions in Table 4). Of the 18 IRRC provisions in the O index, 17 of them do not have a coefficient that is negative and statistically significant in any of the types of regressions used. Indeed, a fair number of them are positive with statistical significance.

With respect to one provision in the $\mathrm{O}$ index, pension parachutes, its coefficient is not statistically significant in regression type (4), negative and significant at the $10 \%$ level in regression types (2) and (3), and negative and significant at the 5\% level in regression type (1). 
The results with respect to the negative effect of pension parachutes on firm valuation are thus mixed, and weaker than the results for each of the entrenching provisions. It is worth noting that pension parachutes are present in only 1\% of firms as of 2002 (and reached a maximum of 5.3\% of firms in 1993). Despite the mixed results and low incidence, the exact correlation between pension parachutes on firm valuation is an issue worth further exploration in future research.

It is important to note that, because of the problem of co-linearity, we do not rule out the possibility that some of the 18 provisions in the $\mathrm{O}$ index are negatively correlated with firm value. We merely note that, using the same method that produced strong and unambiguous results regarding the negative correlation between each of the entrenching provisions and Tobin's Q, we do not obtain similar results with respect to any of the elements of the $\mathrm{O}$ index.

\section{Exploring the issue of simultaneity}

The findings reported so far have established that the E index, and the individual provisions that collectively constitute the E index, are inversely correlated, with economic and statistical significance, with firm valuation. Of course, these findings, by themselves, do not establish that having a higher $\mathrm{E}$ index score is the cause of lower firm valuation. It is possible that the correlation is the result of lower-valued firms adopting entrenching provisions either because low-value firms might be more concerned with hostile takeovers or, alternatively, bad management will tend both to reduce firm valuation and to adopt entrenching provisions. ${ }^{14}$ This issue of simultaneity is often raised with respect to studies that find a correlation between various aspects of firm ownership and structure and firm valuation, and it is notoriously difficult to resolve. $^{15}$

This Section explores this issue of simultaneity. In doing so, we are assisted by the fact that there was a meaningful amount of stability in firms' E index scores over the 1990-2002 period.

\footnotetext{
${ }^{14}$ It is worth noting that the bad management causation story for the documented correlation is hardly a ringing endorsement of entrenching provisions and the managers adopting them.

${ }^{15}$ Part of the problem is that good instruments are difficult to identify in this area. Bhagat and Bolton (2008) use the percentage of stock owned by a firm's directors as an instrument for governance, reasoning that stock ownership can be viewed as a substitute form of governance and that director percentage stock ownership was found not to be related to performance in one study. Although this approach is interesting, it is not clear that directors' ownership percentage should be viewed as a substitute form of governance if it has no effect on performance.
} 
In our data, a firm with a high entrenchment score as of 1990 is likely to have a high entrenchment score in 2002. With respect to some of the entrenching provisions, it is necessary to first obtain shareholder approval before they can be adopted, which made it difficult for firms that did not already have these entrenching provisions as of 1990 to adopt them afterwards. The most notable example of this phenomenon is staggered boards [Bebchuk and Cohen (2005)]. With respect to other entrenching provisions that did not require a shareholder vote-poison pills and golden parachutes-management could unilaterally adopt these provisions. This makes the presence of these two provisions at a particular point in time more likely to be the result of an endogenous firm decision at that point than the other entrenching provisions. Even so, there are some costs to management for suddenly adopting one of these provisions given possibly negative public, institutional investor, and market reaction. It is easier to retain a pre-existing poison pill or golden parachute than to suddenly adopt one.

We examine whether a firm's entrenchment score in 1990, the beginning of our sample period, had a negative correlation with firm valuation in the 1998-2002 period, the years at the end of our sample period. While a firm's 1990 entrenchment score is correlated with the firm's entrenchment score during the 1998-2002 period for the reasons described above, the firm's 1990 entrenchment score cannot itself be the result of low-firm valuation during the 1998-2002 period. Column 1 of Table 8 presents the results of running a regression where the dependent variable is the log of industry-adjusted Tobin's Q and the independent variables are firms' $E$ index scores as of 1990 and firms' other provisions scores in the 1998-2002 period. Column 2 presents the results when dummy variables are used for the different levels of firms' E index scores as of 1990. Both regressions control for the full set of firm characteristics used in earlier regressions.

As the results in Column 1 indicate, a firm's E index score as of 1990 is negatively correlated, with economic and statistical significance (at the 1\% level), with lower firm valuation during the 1998-2002 period. The results when dummies are used for the different levels of the $\mathrm{E}$ index tell the same story. Four out of the five dummy variables are negatively correlated, either at the $1 \%$ or $5 \%$ level, with lower firm valuation. Only the dummy variable representing the lowest entrenchment score, while having a negative coefficient, is not statistically significant.

It might be suggested, however, that poor management at or prior to 1990 was responsible both for the existence of entrenching provisions in 1990 and for the firm's low valuation in the 1998-2002 period. Of course, the likelihood of this explaining the documented 
correlation is weakened by the fact that managerial turnover is common over a 12 year period. Nevertheless, given this possibility, we controlled for the log of firms' industry-adjusted Tobin's Q as of 1990 in the regressions we report in Columns 3 and 4 of Table 8. Low firm valuation as of 1990 helps control for poor management as of 1990. As before, entrenching provisions are negatively correlated, with economic and statistical significance (at the 1\% level), with lower firm valuation. And, as before, four out of the five dummy variables representing the different levels of the E index are negatively correlated, either at the $1 \%$ or $5 \%$ level, with lower firm valuation. Only the dummy variable representing the lowest entrenchment score, while negative, is not statistically significant. ${ }^{16}$

We conclude that, although low-Q firms tended to have high E levels at the end of our sample period, the negative correlation between Tobin's Q and E at the end of our sample period was not all due to the correlation in the beginning of the period; while high-E firms began the period already with lower Q, their Q further declined over time. This is consistent with the possibility that having a higher entrenchment score at least partly brings about (and not merely reflects) lower firm valuation. We should also remind the reader that, as stressed earlier, even if it turned out that the low $\mathrm{Q}$ of high-E firms at the end of the period was all due to their low $\mathrm{Q}$ already in the beginning of the period, that would not imply that entrenchment does not have an effect on firm value; it still could be the case that a high entrenchment level is necessary (and indeed chosen) in order to sustain a low Q level over time without being taken over. In any event, although our evidence is consistent with an effect of entrenchment on value, it does not establish the direction of causation. The issue of simultaneity is one that clearly calls for further examination. $^{17}$

\footnotetext{
${ }^{16}$ We did not extend our analysis to Tobin's Q and E levels prior to 1990 due to lack of data about entrenchment levels prior to 1990. Lehn, Patro, and Zhao (2006) suggest that low Q levels in the early 1980s could not have reflected relatively high entrenchment levels because, based on a subset of firms for which they collected data, the average level of E was low during 1981-1985 data. But even though the average level of $\mathrm{E}$ in their 1981-1985 sample was low, there was a significant variation among firms in $\mathrm{E}$ levels.

${ }^{17}$ Another question with respect to the association between the E index and Tobin's Q that is worthwhile answering concerns identifying how the identified association between $\mathrm{E}$ and Tobin's $\mathrm{Q}$ varies among different subsets of the economy's public firms. This question is explored by Cremers, Nair, and Peyer (2006) and Kadyrzhanova (2006).
} 


\section{ENTRENCHMENT AND STOCK RETURNS}

We next examine the relationship between a firm's E index score and the firm's abnormal stock returns. Much attention has therefore been paid to the findings of Gompers, Ishii, and Metrick (2003) that firms with low GIM index scores were associated with higher abnormal returns during the 1990s compared to those of firms with high GIM index scores. We investigate below whether the identified correlation between returns and the GIM index during the 1990s was attributable to the provisions in the E index.

At the outset, we should stress that for a provision to be associated with a negative abnormal return during a given period time is neither a necessary condition, nor a sufficient condition, for the provision to be negatively correlated with firm value. ${ }^{18}$ The findings on Tobin's $\mathrm{Q}$ might well be more informative than stock return results in identifying provisions that might have adverse effects on shareholders. We also wish to emphasize that the literature has still not resolved how to best interpret the Gompers, Ishii, and Metrick (2003) results concerning abnormal returns. Are these results due to the market learning to appreciate the significance of entrenchment [Gompers, Ishii, and Metrick (2003)], to a correlation between the GIM index and some common risk factor missing from the standard asset pricing model [Cremers, Nair, and John (2006)], or to yet some other factor? This and similar questions are ones on which a consensus is yet to emerge.

For our purposes, which are to identify which IRRC provisions matter, what is most important is not to explain the abnormal return results of Gompers, Ishii, and Metrick (2003) but to examine whether they are driven by the provisions in the E index. Our finding that they do reinforces our earlier conclusion that, within the IRRC provisions universe, the provisions in the E index are those that matter.

Gompers, Ishii, and Metrick (2003) employed the following methodology in calculating the abnormal return associated with differences in GIM index scores. A “Democracy” portfolio was

\footnotetext{
${ }^{18}$ A corporate governance provision that is harmful to shareholders might have no abnormal returns associated with it during a given period if the market accurately assessed the provision's adverse consequences in the beginning of the period. Conversely, a provision that is in fact beneficial to shareholders might be associated with a negative return during a given period if the market viewed it at the end of the period somewhat less positively_although still positively - than in the beginning of the period.
} 
constructed consisting of firms with strong shareholder rights protections, defined as those firms with GIM index scores of 5 or less. Likewise, a "Dictatorship" portfolio was constructed consisting of firms with weak shareholder rights protections, defined as those firms with GIM index scores of 14 or more. The firms in the Democracy and Dictatorship portfolios roughly correspond to the best and worst $10 \%$ of firms in terms of GIM index scores. Democracy and Dictatorship portfolios were constructed both by weighting stock positions by a firm's market capitalization (value-weighted portfolios), as well as by equally weighting each firm (equalweighted portfolios).

Gompers, Ishii, and Metrick (2003) found that the monthly abnormal return for going long the Democracy portfolio and short the Dictatorship portfolio, value-weighted, was 71 basis points with $1 \%$ significance level, and that doing so using equally-weighted portfolios yielded a monthly abnormal return of 45 basis points with $5 \%$ significance. ${ }^{19}$ Their findings of statistically significant abnormal returns applied only to a trading strategy using Democracy and Dictatorship portfolios (firms at the extremes of the GIM index) in its long and short positions. Expanding their testing to a broader spectrum of firms, including firms in the middle of the GIM index distribution, they found no statistically significant abnormal returns resulting from going long firms with low GIM index scores while shorting firms with high GIM index scores.

Our main findings are as follows. Firms with a low E index score are associated with statistically significant abnormal returns both during the 1990-1999 period investigated by Gompers, Ishii, and Metrick (2003), and the longer 1990-2003 time period which our data enables us to study. Moreover, including firms in our trading strategies that are in the middle of the $\mathrm{E}$ index distribution still generates positive monthly abnormal returns with $1 \%$ statistical significance, albeit abnormal returns that are smaller than those generated using firms only with extreme $\mathrm{E}$ index scores. We find that this association between $\mathrm{E}$ index scores and stock returns is not due to the $\mathrm{E}$ index being correlated with IRRC provisions not included in the $\mathrm{E}$ index. Finally, we find that the corporate governance provisions not included in the E index have no explanatory power, above that already provided by the $\mathrm{E}$ index, for returns during the two time periods (1990-1999; 1990-2003) we study.

\footnotetext{
${ }^{19}$ We were able to replicate these basic findings with the Fama-French benchmark factors. We found that the value-weighted trading strategy generated a monthly abnormal return of 73 basis points at the $1 \%$ level, while the equal-weighted trading strategy generated a monthly abnormal return of 49 basis points at the $5 \%$ level.
} 
A. The E index and returns for the 1990s

\section{Summary statistics}

We begin by presenting some basic summary statistics on the E index and stock returns during the 1990s. Table 9 presents the average monthly returns of portfolios of firms, both equally-weighted and valued-weighted, with the same E scores (zero, one, two, three, four, fivesix) for the period of September 1990-December 1999. Interestingly, the average monthly return drops monotonically as one moves from having an entrenchment score of zero to an index score of five and six. The difference between firms with an entrenchment score of zero and firms with an entrenchment score of five or six is quite substantial: $1.74 \%$ versus $1.26 \%$ for equallyweighted portfolios and $2.45 \%$ versus $1.51 \%$ for value-weighted portfolios. Because the returns of value-weighted portfolios can be substantially affected by the returns of a small number of the largest companies, it could be plausibly argued that more attention should be paid to results based on equally-weighted portfolios. But we follow the literature by reporting throughout results based on both equally-weighted and value-weighted portfolios.

This decline in monthly returns as a firm's entrenchment score increases occurs not only when one moves from firms with very low entrenchment scores to firms with very high entrenchment scores but also as entrenchment index scores increase in the middle of the E index distribution. Moreover, the decline in monthly returns as a firm’s entrenchment score increases holds equally true for both equally-weighted and value-weighted portfolios. In both cases, average returns decrease monotonically as one moves to portfolios with higher entrenchment scores.

Obviously, these summary statistics are only suggestive of a possible relationship between the E index and stock returns in the 1990s. To explore this possibility systematically, it is necessary to control for other factors, such as systematic risk, that might be affecting stock returns for firms with different $\mathrm{E}$ index scores. 


\section{The baseline model: controlling for the Fama-French and Carhart four factors}

To identify the correlation between different levels of the $\mathrm{E}$ index and stock returns, we investigated the following question: What was the abnormal return associated with taking a long position in the firms with a given E index score and, at the same time, shorting the firms with a higher $\mathrm{E}$ index score? To answer this question, we follow the methodology of Gompers, Ishii, and Metrick (2003) of regressing the return of this long-short trading strategy for month $t$ (call this variable $\operatorname{Diff}_{t}$ ), on the four-factor model of Carhart (1997). In other words, we ran the following regression:

$$
\operatorname{Diff}_{t}=\mathrm{a}+\mathrm{b} 1 * M K T R F_{t}+\mathrm{b} 2 * H M L_{t}+\mathrm{b} 3 * S M B_{t}+\mathrm{b} 4 * \text { Momentum }_{t}+\mathrm{e}_{\mathrm{t}}
$$

where $M K T R F_{t}$ is the month t value-weighted market return minus the risk-free rate, $S M B_{t}$ and $H M L_{t}$ are the Fama-French zero-investment benchmark factor mimicking portfolios reflecting, respectively, size and book-to-market stock return effects for time $\mathrm{t}$ [see Fama and French (1993)] and Momentum $_{t}$ reflects stock return momentum effects for time t [see Carhart (1997)]. The Fama-French factors were obtained from Kenneth French's datalibrary and the Carhart momentum factor was constructed by us using the procedures described in Carhart (1997). Accordingly, a is construed as the monthly abnormal return associated with going long firms with low E index scores and, simultaneously, shorting firms with high E index scores.

Monthly abnormal returns were calculated using both value-weighted portfolios and equally-weighted portfolios. These hedging portfolios were updated as new information became publicly available concerning the corporate governance provisions firms had. September 1990 is the starting date of the sample period as this was the month that the first IRRC volume was published and became publicly available. Firm membership in portfolios was adjusted on July 1993, July 1995, February 1998, November 1999, and February 2002 as these are the dates when updated IRRC volumes became publicly available.

Table 10 displays the abnormal return results for the 1990s controlling for the Carhart (1997) four factors (the baseline model). These results, regardless of whether one looks at equally-weighted or value-weighted E index portfolios, are striking. During the 1990s, going 
long those firms with the lowest possible entrenchment score (index score of zero) and shorting the high E index portfolio (index scores of five and six), would have generated a monthly abnormal return of 61 basis points with $1 \%$ significance when equal-weighted portfolios are used; and it would have yielded monthly abnormal returns of 116 basis points with $1 \%$ significance when value-weighted portfolios are used. On an annual compounded basis, these strategies would have produced an abnormal return of $7.4 \%$ when equally-weighted portfolios are used and $14.8 \%$ when value-weighted portfolios are used. ${ }^{20}$

There is another interesting pattern that emerges from the baseline model results in Table 10. The abnormal returns are all positive with statistical significance at the $1 \%$ level but progressively decline, whether equally-weighted or value-weighted portfolios are used in the trading strategy, as one includes more and more firms in the middle of the E index distribution. This monotonic decline in abnormal returns as the trading strategies include more firms in the middle of the distribution (with the first trading strategy on the far left being long index level 0short index levels 5-6, then long 0- short 4-6, long 0-1-short 4-6, long 0-1- short 3-6, and finally long 0-2, short 3-6) is illustrated in Figure 1.

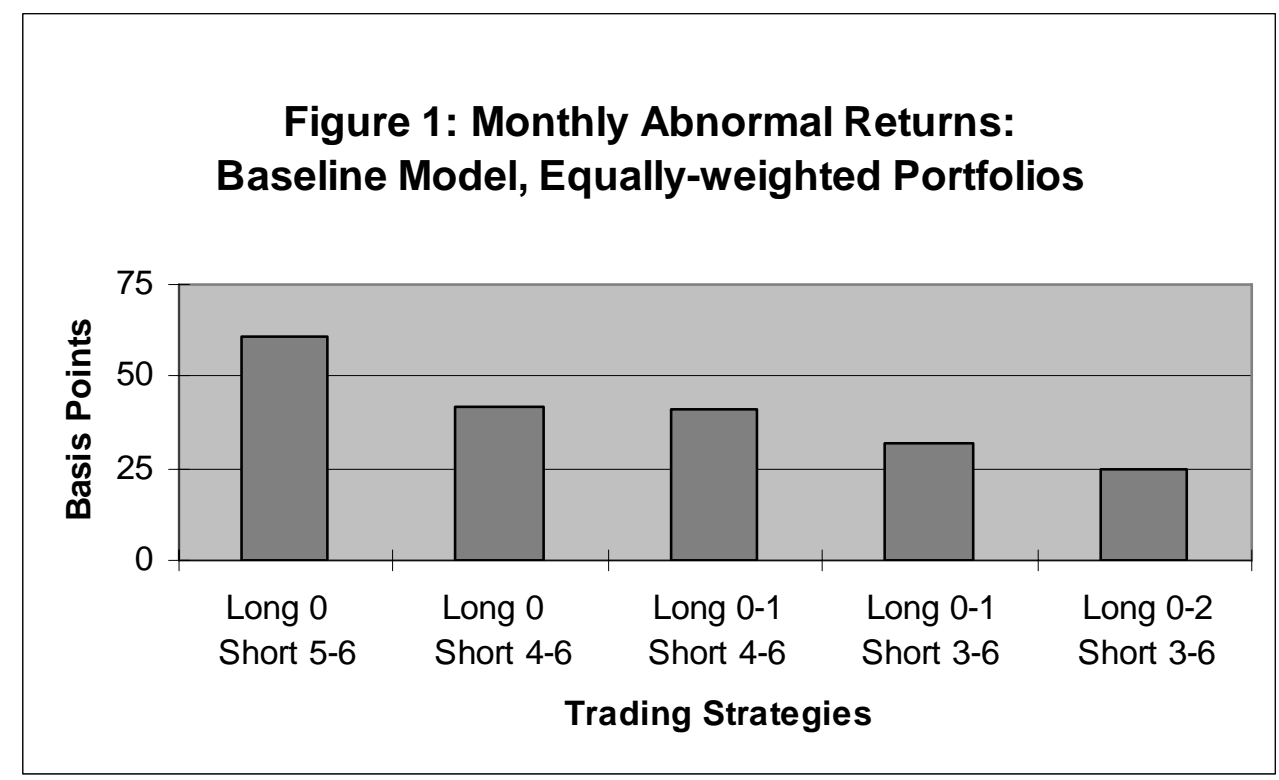

\footnotetext{
${ }^{20}$ These figures are based on compounding the monthly return over the year. Without compounding, the annual abnormal returns would be approximately $7.2 \%$ for a strategy based on equally-weighted portfolios and $13.9 \%$ for a strategy based on value-weighted portfolios.
} 
The same pattern of declining abnormal returns emerges when firms in the middle of the $\mathrm{E}$ index are added to the long and short positions (with the first trading strategy on the far left again being long 0 -short 5-6, then long 0 -short 4-6, long 0-1-short 4-6, long 0-1-short 3-6, and finally long 0-2-short 3-6) when value-weighted portfolios are used (Figure 2).

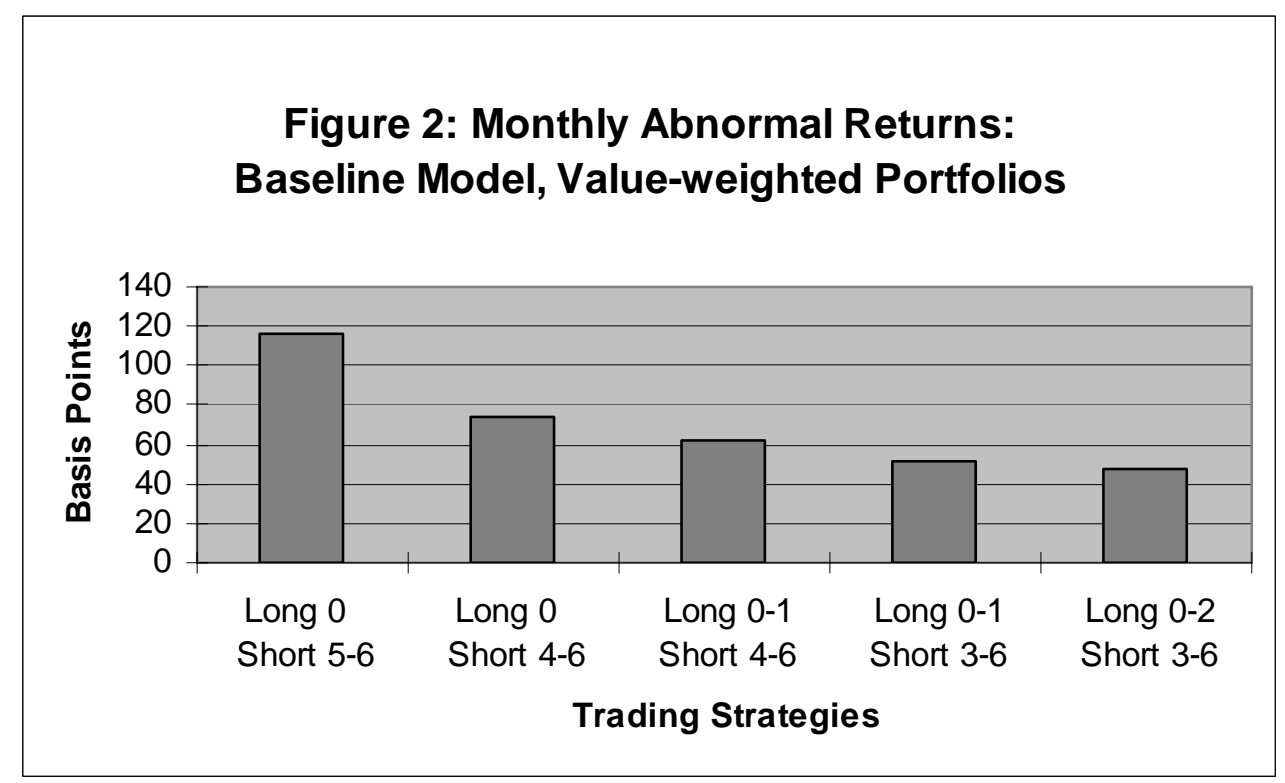

This monotonic decline in abnormal returns is to be expected if stock returns are negatively correlated with the degree to which managers are entrenched as captured by the $\mathrm{E}$ index.

\section{Industry-adjusted returns}

There is, of course, always the possibility that a firm's corporate governance provisions merely reflect the industry in which the firm happens to operate. That is, it might be that low entrenchment levels were more common in industries that happened to perform well in terms of returns during the 1990s, and that the above findings of abnormal returns were driven by industry association. We therefore control for industry effects on stock returns in the same manner as Gompers, Ishii, and Metrick (2003).

In particular, we classified all the firms in our dataset into one of the 48 Fama-French (1997) industry classifications, and then calculated industry-adjusted monthly returns by first subtracting from each firm's monthly stock return the median monthly industry return for the 
Fama-French industry in which the firm operates. Monthly abnormal industry-adjusted returns on a trading strategy were then calculated by regressing the industry-adjusted returns associated with this strategy (going long firms with a particular E index score and, simultaneously, shorting other firms with a higher E index score) on the three Fama-French factors [Fama and French (1993)] and a momentum factor [Carhart (1997)]. The industry-adjusted monthly abnormal returns were calculated for the same trading strategies analyzed in the baseline model. The results are also reported in Table 10.

As Table 10 indicates, all the long-short portfolios continue to generate positive abnormal returns that are all statistically significant at the $1 \%$ level. Also, once again, as one adds firms with index scores in the middle of the distribution to the long and short portfolios, the industryadjusted monthly abnormal returns monotonically decrease. Finally, the industry-adjusted return estimates are approximately the same as those estimated without adjusting for industry. In short, the abnormal return results generated using the baseline model do not appear to be driven by industry effects.

\section{Controlling for other governance provisions}

One potential issue with the preceding analysis is the fact that the E index is correlated with other corporate governance provisions covered by the IRRC. Recall that the correlation between the $\mathrm{E}$ index and the $\mathrm{O}$ index is about 0.3-0.35 during the period of our study. This makes it desirable to examine whether the results associating higher abnormal returns with lower E index scores are due to a correlation between returns and the $\mathrm{O}$ index.

To address this issue, we calculate the results of a new set of trading strategies that seek to control for the provisions in the $\mathrm{O}$ index. We wish to test whether, within pools of firms that have similar levels of the $\mathrm{O}$ index, going long on low entrenchment companies and short on high entrenchment companies continues to produce positive abnormal returns.

Specifically, we start by dividing all firms into four buckets based on their $\mathrm{O}$ index score. The four buckets were created so as to contain, to the extent possible, equal numbers of observations. The four buckets of firms consist of firms with low $\mathrm{O}$ index scores (index score of five or less); firms with medium-low O index scores (index score of six); firms with mediumhigh $\mathrm{O}$ index scores (index scores of seven and eight); and firms with high $\mathrm{O}$ index scores (index 
scores of nine or more). In addition, we used several different divisions of the $\mathrm{O}$ index into buckets and found that using them does not affect the results.

With these $\mathrm{O}$ buckets in place, we were able to take into account the $\mathrm{O}$ distribution, as captured by the four buckets, when calculating abnormal returns associated with going long firms with low E index scores and short high $\mathrm{E}$ index firms. ${ }^{21}$ When considering a trading strategy of going long firms with a given low E index score level and short firms with a given high $\mathrm{E}$ index score level, we would for each $\mathrm{O}$ index bucket create positions (either equallyweighted or value-weighted) consisting of going long all the firms with the given low entrenchment level and short all the firms with the given high entrenchment level in that $\mathrm{O}$ index bucket. We then created an overall long-short portfolio consisting of an equally-weighted position in each of the four long and short positions created for the four $\mathrm{O}$ index buckets. As before, we then regressed the return associated with this long-short portfolio on the Carhart (1997) four-factor model, with the intercept term being interpreted as the monthly abnormal return associated with this particular trading strategy.

The basic idea behind constructing portfolios in this way is to ensure that, in constructing our long-short portfolios, the firms purchased and shorted are different in their E index scores while still being roughly similar in their $\mathrm{O}$ index scores. The method is analytically similar to the way in which the Fama-French book-to-market and firm size factors are calculated [see Fama and French (1993)] as well as the Carhart momentum factor construction [see Carhart (1997)].

The same trading strategies analyzed earlier were used once again. The results, which are reported in Table 10, indicate that relatively little changes after we control for correlation with the $\mathrm{O}$ index. The abnormal returns remain positive and statistically significant at the $1 \%$ level, with one exception that is positive and significant at the $5 \%$ level. Moreover, the abnormal return estimates are of roughly similar magnitudes. For instance, the monthly abnormal return of going long firms in the bottom half of the distribution and short the top half is 23 basis points for equalweighted portfolios and 50 basis points for value-weighted portfolios, both with $1 \%$ significance. Also, the same pattern of decreasing abnormal returns again emerges when looking at the effect of adding firms in the middle of the $\mathrm{E}$ index distribution to the long and short portfolios.

\footnotetext{
${ }^{21}$ It is impossible to do an exact $\mathrm{O}$ index distribution given a lack of sufficient firm observations across the entrenchment index to replicate the $\mathrm{O}$ index distribution.
} 


\section{B. The E index and returns for 1990-2003}

Following the initial finding by Gompers, Ishii, and Metrick (2003) of correlation between the GIM index and lower stock returns during the period 1990-1999, subsequent work did not find such correlation in a period extended forward to include the beginning of this decade [Cremers and Nair (2005)]. The question therefore naturally arises whether the trading strategies analyzed above, going long firms with low $\mathrm{E}$ index scores and shorting firms with higher $\mathrm{E}$ index scores, would have yielded abnormal returns in the 1990-2003 period.

Turning to this question, we calculated for the period 1990-2003 the abnormal returns for different trading strategies using the Carhart (1997) four factors (the baseline model), the industry-adjusted model, and the O-bucket adjusted model. The results are summarized in Table 11.

As Table 11 indicates, all the trading strategies, going long on low entrenchment firms and short on high entrenchment firms, continue to produce positive abnormal returns that are large and statistically significant at the $1 \%$ level. Furthermore, for both the equal-weighted and valueweighted portfolios, abnormal returns on trading strategies largely continue to decline monotonically as firms in the middle of the E index are added to the long and short portfolios. This overall pattern emerges in the baseline model, the industry-adjusted model, and the Obucket-adjusted model.

In terms of the magnitude of the abnormal returns, the results for the period 1990-2003 are roughly similar to the results for the period 1990-1999 when the trading strategies use equallyweighted portfolios. For example, going long E index zero and short index five or six, would have yielded 61 basis points during 1990-1999 and 60 basis points during 1990-2003 using the baseline four-factor model; would have yielded 60 basis points during 1990-1999 and 66 basis points during 1990-2003 using the industry-adjusted model; and would have yielded 73 basis points during 1990-1999 and 68 basis points during 1990-2003 using the O-bucket-adjusted model. Similarly, when going long firms with E index scores of two or less and shorting the firms with index three or more, moving from 1990-1999 to 1990-2003 would have increased the monthly abnormal return by two basis points (to 27 basis points) under the baseline model; by 8 basis points (to 34 basis points) under the industry-adjusted model; and one basis point (to 24 basis points) under the O-bucket-adjusted model. 
For trading strategies using value-weighted portfolios, the abnormal returns for the 19902003 period are significantly smaller than the corresponding trading profits for the 1990-1999 period. The trading profits using value-weighted portfolios in the 1990-2003, however, continue to be quite large in magnitude and, in particular, higher than the abnormal return on the corresponding strategies using equally-weighted portfolios during either the 1990-1999 or the 1990-2003 period. For example, during 1990-2003, using value-weightings, going long E index zero firms and shorting index five or six firms would have yielded a monthly positive abnormal return of 84 basis points under the baseline model; 94 basis points under the industry-adjusted model; and 81 basis points under the O-bucket-adjusted model. In contrast, using equalweightings, going long index zero firms and shorting index five or six firms during 1990-1999 would have yielded only a monthly positive abnormal return of 61 basis points under the baseline model (or 60 basis points if the period were extended to 2003); 60 basis points under the industry-adjusted model (or 66 if the period were extended to 2003); and 73 basis points under the O-bucket-adjusted model (or 68 if the period were extended to 2003).

\section{Stock returns and the $O$ index}

We have found that, even controlling for the $\mathrm{O}$ index, the E index was correlated with stock returns during the period we study. There is still the possibility, however, that the $\mathrm{O}$ index was also correlated, controlling for the E index level, with stock returns. In other words, it is possible to flip the inquiry and ask whether the $\mathrm{O}$ index, the IRRC corporate governance provisions not reflected in the E index, has explanatory power for stock returns.

Accordingly, we calculated the abnormal returns associated with firms' $O$ index scores, controlling for the E index distribution as captured by different E index buckets. To this end, we created six E index buckets, each consisting of all the firms in a given level of the index from zero to five, with the small number of firms with $\mathrm{E}$ index six scores added to the bucket with $\mathrm{E}$ index five firms. Following the methodology described earlier, we would for each $\mathrm{E}$ index bucket create positions (either equally-weighted or value-weighted) consisting of going long all the firms with a given low $\mathrm{O}$ index score and short all the firms with a given high $\mathrm{O}$ index score in that E level bucket. After doing this, we then created an overall long-short portfolio consisting of an equally-weighted position in each of the six long and short positions created for the six E 
index buckets. As always, we regressed the return associated with this long-short portfolio on the Carhart (1997) four-factor model, with the intercept term being interpreted as the monthly abnormal return associated with this particular trading strategy.

We did the calculations both for the 1990-1999 period and for the 1990-2003 period. The long-short portfolios in $\mathrm{O}$ index positions were based on the division of firms into four $\mathrm{O}$ index buckets: firms with $\mathrm{O}$ index scores between zero and five; firms with $\mathrm{O}$ index scores of six; firms with $\mathrm{O}$ index scores of seven or eight; and firms with $\mathrm{O}$ index scores of nine and more. Table 12 contains the results of this analysis.

Out of the sixteen trading strategies analyzed, consisting of going long firms with low $\mathrm{O}$ index levels and short firms with high $\mathrm{O}$ index levels, none generated statistically significant abnormal returns, even at the $10 \%$ level. Indeed, many of the t-statistics indicate p-values in the range of $80 \%$. In addition to the lack of statistical significance, the coefficients are sometimes negative rather than positive and always small in magnitude, never exceeding 0.17 . These results are consistent with the view that the $\mathrm{O}$ index has little residual explanatory power for returns once the $\mathrm{E}$ index is taken into account.

\section{CONCLUDING REMARKS}

This paper has identified which provisions, among the set of 24 IRRC provisions used in the GIM governance index, are negatively correlated with firm performance. We have identified six entrenching provisions that are negatively correlated with firm valuation, as measured by Tobin's Q, as well as with stock returns during the 1990-2003 period. We have also found that these provisions fully drive the findings documented by prior research that the IRRC provisions in the aggregate are correlated with Tobin’ Q, as well as returns during the 1990s.

Our results contribute to our understanding of the relationship between governance and firm value, and provide a basis for future work in several ways. The $\mathrm{E}$ index provides a measure that can be used, and is already being used in a large number of studies, by researchers seeking to use in their tests a governance measure not influenced by the noise produced by the other IRRC provisions. The six provisions in the $\mathrm{E}$ index are those which researchers, as well as private and public decision-makers, should pay most attention. And knowing which provisions matter also 
provides a useful tool in the inquiry into the cause of the correlation between the IRRC provisions in the aggregate and firm value.

Pursuing fully this inquiry is an important task for future work. We present some evidence that is consistent with the possibility that, in the aggregate, the entrenching provisions bring about or help maintain lower firm valuation. But this evidence does not establish causality and much more work needs to be done. With the key provisions responsible for the correlation with firm value now known, it will be possible to examine whether the answers to these questions vary among the provisions in the E index. We conjecture that the constitutional limitations on shareholder power do bring about, and not merely reflect, lower firm value. In contrast, we conjecture that the correlation that poison pills and golden parachutes have with lower firm value at least partly reflects the greater tendency of managers of firms with lower firm value to adopt takeover readiness provisions.

In constructing the E index, we have followed the standard approach of giving each of the provisions an equal weight and not making this weight conditional on the presence (or absence) of other provisions that might interact with it. An important avenue for future work to explore is the possibility of improving the index by exploring the possibility that the some of the provisions in the $\mathrm{E}$ index matter more than others and that interactions among them (e.g., having a combination of a staggered board and a poison pill) are important.

Looking beyond the set of IRRC provisions, our analysis cautions against the "kitchen sink" approach of building ever-larger indexes of governance measures. Shareholder advisory firms, including industry leader ISS, have put forward indexes of good corporate governance based on a massive number of provisions, and the development and use of these indexes has put pressure on firms to adjust their arrangements in ways that would improve their index scores. As this paper highlights, in any large set of governance provisions, many are likely not to matter or to be an endogenous product of others. Compared with a governance rating scheme based on the key provisions that matter, a governance rating system based on a much larger set can push firms in directions that are counter-productive or at least wasteful, and provides a noisier measure of governance quality. In short, adding more provisions to an index is hardly bound to be beneficial; in this area, less can be more. Shareholders and their advisers might do well to focus on those corporate governance provisions that really matter for firm value. 


\section{APPENDIX: IRRC DEFINITIONS OF THE 24 PROVISIONS}

Entrenchment index provisions

Staggered Board: A board in which directors are divided into separate classes (typically three) with each class being elected to overlapping terms.

Limitation on Amending Bylaws: A provision limiting shareholders’ ability through majority vote to amend the corporate bylaws.

Limitation on Amending the Charter: A provision limiting shareholders' ability through majority vote to amend the corporate charter.

Supermajority to Approve a Merger: A requirement that requires more than a majority of shareholders to approve a merger.

Golden Parachute: A severance agreement that provides benefits to management/board members in the event of firing, demotion or resignation following a change in control.

Poison Pill: A shareholder right that is triggered in the event of an unauthorized change in control that typically renders the target company financially unattractive or dilutes the voting power of the acquirer. 
Other provisions index provisions

Limitation on Special Meeting: A provision limiting shareholders' ability to act by calling a special meeting (as opposed to waiting for the regularly scheduled shareholders' meeting)

Limitation on Written Consent: A provision limiting shareholders' ability to act via written consent (as opposed to acting through a vote at the shareholders' meeting)

Elimination of Cumulative Voting: A provision eliminating shareholders' ability to apportion their votes in an election.

Secret Ballot: A system of voting that ensures management does not look at individual proxy cards.

Director Indemnification: A charter or bylaw provision indemnifying the firm's officers and directors against certain legal expenses and judgments as a result of their conduct.

Director Indemnification Contract: A contract with individual officers and directors promising indemnification against certain legal expenses and judgments as a result of their conduct.

Limited Director Liability: A provision that limits the personal liability of its directors.

Compensation Plan: A plan that accelerates benefits in the event of a change in control. 
Severance Agreement: A contract which ensures executives some income protection in the event of losing their positions.

Unequal Voting Rights: A provision by which voting power changes based on certain conditions.

Blank Check Preferred Stock: This is stock that, when authorized, gives the board broad discretion in establishing the stock's voting, dividend and other rights when issued.

Fair Price Requirements: A requirement that a bidder pay all shareholders a "fair price," typically the highest price paid by a bidder prior to a tender offer being made.

Cash-out Law: A provision that enables shareholders to sell to a controlling shareholder, usually at the highest price recently paid by the controlling shareholder.

Director Duties: A provision that permits the board to consider non-shareholder interests in evaluating a possible change in control.

Business Combination Law: A law that limits the ability of an acquirer to conduct certain transactions with the acquired company post-acquisition.

Antigreenmail Provision: A provision that prevents an entity from acquiring a block of stock in a company and selling it back to the company at an above-market price. 
Pension Parachute: Provisions that limit the ability of an acquirer from using surplus money in a pension plan to fund the acquisition.

Silver Parachute: A severance agreement that provides benefits to a large number of firm employees in the event of firing, demotion or resignation following a change in control. 


\section{References}

Amit, R. and B. Villalonga. 2006. How Do Family Ownership, Control, and Management Affect Firm Value? Journal of Financial Economics, 80, 385-417.

Bates, T., D. Becher, and M. Lemmon. 2008. Board Classification and Managerial Entrenchment: Evidence from the Market for Corporate Control. Journal of Financial Economics, 87, 656-677.

Bebchuk, L.. 2002. The Case against Board Veto in Corporate Takeovers. University of Chicago Law Review, 69, 973-1035.

Bebchuk, L., J. Coates and G. Subramanian. 2002. The Powerful Antitakeover Force of Staggered Boards: Theory, Evidence \& Policy. Stanford Law Review, 54, 887-951.

Bebchuk, L., J. Coates and G. Subramanian. 2003. The Power of Takeover Defenses. Working paper, Harvard Law School and NBER.

Bebchuk, L. and A. Cohen. 2005. The Costs of Entrenched Boards. Journal of Financial Economics, 78, 409-433.

Bebchuk, L., A. Cohen, and A. Ferrell. 2004. What Matters in Corporate Governance? Discussion Paper No. 491, John M. Olin Center for Law Economics, and Business, Harvard Law School.

Bebchuk, L., A. Cohen, and C. Wang. 2008. Golden Parachutes and Corporate Acquisitions. Working Paper, Harvard Law School and NBER.

Bebchuk, L. and J. Fried. 2004. Pay without Performance: The Unfulfilled Promise of Executive Compensation.

Bebchuk, L. and L. Stole. 1993. Do Short-Term Managerial Objectives Lead to Under- or OverInvestment in Long-Term Projects? Journal of Finance, 48, 719-729.

Bertrand, M. and S. Mullainathan. 1999. Is There Discretion in Wage Setting? Rand Journal of Economics, 30, 535-554.

Bertrand, M. and S. Mullainathan. 2003. Enjoying the Quiet Life? Managerial Behavior Following Anti-Takeover Legislation. Journal of Political Economy, 11, 1043-1075.

Bhagat, S. and B. Bolton. 2008. Corporate Governance and Firm Performance. Journal of Corporate Finance, 14, 257-273. 
Black, B., B. Cheffins and M. Klausner. 2006. Outside Director Liability. Stanford Law Review, 58, 1055-1159.

Borokhovich, K., Kelly B., and R. Parrino. 1997. CEO Contracting and Antitakeover Amendments. Journal of Finance, 52, 1495-1517.

Brown, L. and M. Caylor. 2006. Corporate Governance and Firm Valuation, Journal of Accounting and Public Policy, 25, 409-434.

Clark, R.. 1986. Corporate Law, Brown, Little.

Carhart, M.. 1997. On Persistence in Mutual Fund Performance. Journal of Finance 52, 57-82.

Coates, J.. 2000. Takeover Defenses in the Shadow of the Pill: A Critique of the Scientific Evidence. Texas Law Review, 79, 271-382.

Chung, K. and S. Pruitt. 1994. A Simple Approximation of Tobin’s Q. Financial Management 23, 70-74.

Cremers, M. and V. Nair, 2005. Governance Mechanisms and Equity Prices. Journal of Finance, 60, 2859-2894.

Cremers, M., V. Nair, and K. John. 2006. Takeovers and the Cross-Section of Returns. forthcoming Review of Financial Studies.

Cremers, M., V. Nair and C. Wei. 2007. Governance Mechanisms and Bond Prices. Review of Financial Studies, 20, 1359-1388.

Cremers, M., V. Nair and U. Peyer. 2006. Takeover Defenses and Competition. forthcoming Journal of Empirical Legal Studies.

Daines, R.. 2001. Does Delaware Law Improve Firm Value? Journal of Financial Economics, 62, 559-571.

Demsetz, H. and K. Lehn. 1985. The Structure of Corporate Ownership: Causes and Consequences. Journal of Political Economy, 93, 1155-1177.

Dittmar, A. and J. Mahrt-Smith. 2007. Corporate Governance and the Value of Cash Holdings. Journal of Financial Economics, 83, 599-634.

Faleye, O.. 2007. Classified Boards, Firm Value, and Managerial Entrenchment. Journal of Financial Economics 83, 501-529.

Fama, E. and K. French, 1993. Common Risk Factors in the Returns on Bonds and Stocks. Journal of Financial Economics 33, 3-53. 
Fama, E. and K. French. 1997. Industry Costs of Equity. Journal of Financial Economics, 93, 153-194.

Garvey, G. and G. Hanka. 1999. Capital Structure and Corporate Control: The Effect of Antitakeover Statutes on Firm Leverage. Journal of Finance, 54, 519-546.

Georgeson Shareholder. 2003. Annual Corporate Governance Review.

Georgeson Shareholder. 2004. Annual Corporate Governance Review.

Gompers, P., J. Ishii, and A. Metrick. 2003. Corporate Governance and Equity Prices. Quarterly Journal of Economics, 118, 107-155.

Guo, R., T. Kruse, and T. Nohel. 2008. Undoing the Powerful Anti-takeover Force of Staggered Boards. Journal of Corporate Finance, 14, 274-288.

Harford, J., S. Mansi, and W. Maxwell. 2008. Corporate Governance and Firm Cash Holdings. Journal of Financial Economics, 87, 535-555.

Investor Responsibility Research Center (IRRC) (1990, 1993, 1995, 1998, 2000, 2002), Corporate Takeover Defenses.

John, K. and L. Litov. 2006. Corporate Governance and Financing Policy: New Evidence. Working Paper, Olin School of Business and Stern School.

Johnson, M. and R. Rao. 1997. The Impact of Antitakeover Amendments on Corporate Financial Performance. Financial Review, 32, 659-690.

Kadyrzhanova, D.. 2006. Does Governance Pay, or Is Entrenchment the Way? Merger Gains and Antitakeover Provisions. Working Paper, Columbia University.

Kaplan, S. and L. Zingales. 1997. Do Investment-Cash Flow Sensitivities Provide Useful Measures of Financing Constraints? Quarterly Journal of Economics, 112, 169-216.

Klock, M., S. Mansi and W. Maxwell. 2005. Does Corporate Governance Matter to Bondholders? Journal of Financial and Quantitative Analysis, 40, 693-719.

Lambert, R. and D. Larker. 1985. Golden Parachutes, Executive Decision-Making and Shareholder Wealth. Journal of Accounting and Economics, 7, 179-203.

Lang, L. and R. Stulz. 1994. Tobin's Q, Corporate Diversification, and Firm Performance. Journal of Political Economy, 102, 1248-1280.

La Porta, R., F. Lopez-de-Silanes, A. Shleifer, and R. Vishny. 1998. Law and Finance. Journal of Political Economy, 106, 1113-1155. 
La Porta, R., F. Lopez-de-Silanes, A. Shleifer, and R. Vishny. 2002. Investor Protection and Corporate Valuation. Journal of Finance, 57, 1147-1170.

Lehn, K., S. Patro, and M. Zhao. 2006. Governance Indices and Valuation Multiples: Which Causes Which? Working Paper, University of Pittsburgh and Bentley College.

Manne, H.. 1965. Mergers and the Market for Corporate Control. Journal of Political Economy, 73, 110-120.

Masulis, W. C. Wang and F. Xie, 2007, Corporate Governance and Acquirer Returns. Journal of Finance. 39, 1851-1889.

McConnell, J. and H. Servaes. 1990. Additional Evidence on Equity Ownership and Corporate Value. Journal of Financial Economics, 27, 595-612.

Morck, R., A. Shleifer, and R. Vishny. 1988. Management Ownership and Market Valuation: An Empirical Analysis. Journal of Financial Economics, 20, 293-315.

Perez-Gonzalez, F.. 2006. Inherited Control and Firm Performance. American Economic Review, 30, 1559-1588.

Ryngaert, M.. 1988. The Effect of Poison Pill Securities on Shareholder Wealth. Journal of Financial Economics, 20, 377-417.

Shin, H. and R. Stulz. 2000. Firm Value, Risk, and Growth Opportunities. NBER Working Paper No. 7808.

Stein, J.. 1988. Takeover Threats and Managerial Myopia. Journal of Political Economy, 96, 6180.

Stulz, R.. 1988. Managerial Control of Voting Rights. Journal of Financial Economics, 20, 2554.

White, H.. 1980. A Heteroskedasticity-Consistent Covariance Matrix Estimator and a Direct Test for Heteroskedasticity. Econometrica, 48, 817-838.

Wilcox, J.. 2002. Tow Cheers for Staggered Boards. Corporate Governance Advisor, 10, 1-5. 
TABLE I: INCIDENCE OF CORPORATE GOVERNANCE PROVISIONS

\begin{tabular}{|c|c|c|c|c|c|c|}
\hline & \multicolumn{6}{|c|}{ YEAR } \\
\hline & 1990 & 1993 & 1995 & 1998 & 2000 & 2002 \\
\hline \multicolumn{7}{|l|}{ Entrenchment Index Provisions: } \\
\hline Staggered Board & $59.2 \%$ & $60.5 \%$ & $61.8 \%$ & $59.5 \%$ & $60.5 \%$ & $61.9 \%$ \\
\hline Limits to Amend Bylaws & $14.5 \%$ & $16.2 \%$ & $16.1 \%$ & $18.2 \%$ & $20.0 \%$ & $23.2 \%$ \\
\hline Limits to Amend Charter & $3.3 \%$ & $3.4 \%$ & $3.1 \%$ & $3.0 \%$ & $3.3 \%$ & $2.5 \%$ \\
\hline Supermajority & $39.0 \%$ & $39.5 \%$ & $38.4 \%$ & $34.1 \%$ & $34.1 \%$ & $32.3 \%$ \\
\hline Golden Parachutes & $53.3 \%$ & $55.7 \%$ & $55.2 \%$ & $56.9 \%$ & $67.4 \%$ & $70.2 \%$ \\
\hline Poison Pill & $54.4 \%$ & $57.6 \%$ & $56.6 \%$ & $55.4 \%$ & $59.9 \%$ & $59.0 \%$ \\
\hline \multicolumn{7}{|l|}{ All Other Provisions: } \\
\hline Limits to Special Meeting & $24.8 \%$ & $30.0 \%$ & $32.0 \%$ & $34.8 \%$ & $38.3 \%$ & $50.2 \%$ \\
\hline Limits to Written Consent & $24.8 \%$ & $29.3 \%$ & $32.1 \%$ & $33.3 \%$ & $36.2 \%$ & $46.4 \%$ \\
\hline No Cumulative Vote & $81.6 \%$ & $83.6 \%$ & $85.0 \%$ & $87.8 \%$ & $89.0 \%$ & $90.4 \%$ \\
\hline No Secret Ballot & $97.1 \%$ & $90.5 \%$ & $87.8 \%$ & $90.4 \%$ & $89.1 \%$ & $88.8 \%$ \\
\hline Director Indemnification & $40.8 \%$ & $39.5 \%$ & $38.5 \%$ & $24.5 \%$ & $23.6 \%$ & $19.1 \%$ \\
\hline Director Indemnification Contracts & $16.6 \%$ & $15.2 \%$ & $12.6 \%$ & $11.2 \%$ & $9.1 \%$ & $8.1 \%$ \\
\hline Director Liability & $72.7 \%$ & $69.2 \%$ & $65.5 \%$ & $47.2 \%$ & $43.1 \%$ & $33.9 \%$ \\
\hline Compensation Plans & $45.3 \%$ & $66.1 \%$ & $72.8 \%$ & $63.2 \%$ & $72.6 \%$ & $74.0 \%$ \\
\hline Severance Agreements & $13.1 \%$ & $5.5 \%$ & $10.2 \%$ & $11.2 \%$ & $9.2 \%$ & $6.1 \%$ \\
\hline Unequal Vote & $2.4 \%$ & $2.0 \%$ & $1.9 \%$ & $1.7 \%$ & $1.5 \%$ & $1.6 \%$ \\
\hline Blank Check & $76.7 \%$ & $80.1 \%$ & $85.9 \%$ & $88.0 \%$ & $89.4 \%$ & $90.8 \%$ \\
\hline Fair Price & $58.0 \%$ & $59.1 \%$ & $57.6 \%$ & $49.4 \%$ & $48.5 \%$ & $44.0 \%$ \\
\hline Cash Out Law & $4.1 \%$ & $3.7 \%$ & $3.6 \%$ & $3.1 \%$ & $2.7 \%$ & $2.5 \%$ \\
\hline Director Duties & $10.4 \%$ & $11.1 \%$ & $10.9 \%$ & $9.9 \%$ & $10.2 \%$ & $10.8 \%$ \\
\hline Business Combination Law & $84.1 \%$ & $87.5 \%$ & $87.4 \%$ & $88.4 \%$ & $89.0 \%$ & $89.1 \%$ \\
\hline Anti-green Mail & $19.7 \%$ & $20.8 \%$ & $20.1 \%$ & $17.1 \%$ & $15.8 \%$ & $15.0 \%$ \\
\hline Pension Parachutes & $4.0 \%$ & $5.3 \%$ & $4.0 \%$ & $2.2 \%$ & $1.5 \%$ & $1.0 \%$ \\
\hline Silver Parachutes & $4.1 \%$ & $4.9 \%$ & $3.5 \%$ & $2.4 \%$ & $2.0 \%$ & $1.7 \%$ \\
\hline
\end{tabular}


TABLE II: INCIDENCE OF THE ENTRENCHMENT INDEX

\begin{tabular}{c|cccccc}
\hline \hline $\begin{array}{c}\text { Entrenchment } \\
\text { Index }\end{array}$ & 1990 & 1993 & 1995 & 1998 & 2000 & 2002 \\
\hline 0 & $13.0 \%$ & $11.0 \%$ & $11.0 \%$ & $10.7 \%$ & $7.9 \%$ & $7.3 \%$ \\
1 & $18.2 \%$ & $17.3 \%$ & $17.6 \%$ & $19.0 \%$ & $18.0 \%$ & $15.4 \%$ \\
2 & $24.3 \%$ & $25.0 \%$ & $25.4 \%$ & $25.9 \%$ & $24.0 \%$ & $26.8 \%$ \\
3 & $25.4 \%$ & $25.7 \%$ & $25.3 \%$ & $25.1 \%$ & $27.6 \%$ & $27.2 \%$ \\
4 & $14.7 \%$ & $16.3 \%$ & $16.7 \%$ & $15.9 \%$ & $18.2 \%$ & $18.3 \%$ \\
5 & $3.7 \%$ & $4.3 \%$ & $3.8 \%$ & $2.8 \%$ & $3.8 \%$ & $4.6 \%$ \\
6 & $0.7 \%$ & $0.4 \%$ & $0.2 \%$ & $0.6 \%$ & $0.5 \%$ & $0.4 \%$ \\
\hline \hline
\end{tabular}

TABLE III: INCIDENCE OF OTHER PROVISIONS INDEX

\begin{tabular}{c|cccccccc}
\hline $\begin{array}{c}\text { Index of } \\
\text { Other } \\
\text { Provisions }\end{array}$ & 1990 & 1993 & 1995 & 1998 & 2000 & 2002 & $\begin{array}{c}\text { Average } \\
\text { E-Index: } \\
\text { Year 1990 }\end{array}$ & $\begin{array}{c}\text { Average } \\
\text { E-Index: } \\
\text { Year 2002 }\end{array}$ \\
\hline 1 & $0.15 \%$ & $0.00 \%$ & $0.00 \%$ & $0.00 \%$ & $0.06 \%$ & $0.00 \%$ & 1.50 & 1.11 \\
2 & $1.41 \%$ & $0.68 \%$ & $0.66 \%$ & $0.71 \%$ & $0.52 \%$ & $0.55 \%$ & 0.89 & 1.41 \\
3 & $3.72 \%$ & $3.68 \%$ & $2.41 \%$ & $3.12 \%$ & $2.14 \%$ & $1.64 \%$ & 1.42 & 1.61 \\
4 & $7.58 \%$ & $6.38 \%$ & $5.41 \%$ & $10.88 \%$ & $8.31 \%$ & $7.71 \%$ & 1.67 & 2.10 \\
5 & $14.94 \%$ & $12.91 \%$ & $13.38 \%$ & $17.82 \%$ & $17.85 \%$ & $15.79 \%$ & 1.75 & 2.24 \\
6 & $19.03 \%$ & $17.87 \%$ & $17.98 \%$ & $17.24 \%$ & $18.23 \%$ & $21.86 \%$ & 2.09 & 2.72 \\
7 & $16.36 \%$ & $16.97 \%$ & $16.81 \%$ & $16.53 \%$ & $19.92 \%$ & $22.16 \%$ & 2.36 & 2.90 \\
8 & $15.24 \%$ & $17.49 \%$ & $19.52 \%$ & $14.88 \%$ & $14.99 \%$ & $13.60 \%$ & 2.52 & 2.86 \\
9 & $10.26 \%$ & $12.01 \%$ & $11.77 \%$ & $9.59 \%$ & $9.28 \%$ & $8.50 \%$ & 2.78 & 3.33 \\
10 & $7.21 \%$ & $6.76 \%$ & $6.94 \%$ & $5.71 \%$ & $5.78 \%$ & $5.04 \%$ & 3.01 & 3.44 \\
11 & $3.35 \%$ & $4.28 \%$ & $4.24 \%$ & $2.71 \%$ & $2.14 \%$ & $2.37 \%$ & 3.04 & 3.38 \\
12 & $0.45 \%$ & $0.75 \%$ & $0.66 \%$ & $0.65 \%$ & $0.65 \%$ & $0.49 \%$ & 2.17 & 3.40 \\
13 & $0.30 \%$ & $0.23 \%$ & $0.22 \%$ & $0.18 \%$ & $0.13 \%$ & $0.30 \%$ & 2.25 & 1.11 \\
\hline Average & & & & & & & 2.24 & 2.49 \\
Total & $100.00 \%$ & $100.00 \%$ & $100.00 \%$ & $100.00 \%$ & $100.00 \%$ & $100.00 \%$ & & \\
\hline \hline
\end{tabular}




\section{TABLE IV: THE ENTRENCHMENT INDEX AND FIRM VALUE}

This table reports pooled OLS regressions of log (industry-adjusted Tobin's q) on various controls and two specifications of the entrenchment index. Tobin's q is the ratio of the market value of assets to the book value of assets, where the market value of assets is computed as book value of assets plus the market value of common stock less the sum of book value of common stock and balance sheet deferred taxes. Industry-adjusted Tobin's q is equal to Tobin's q minus the median Tobin's q in the industry, where industry is defined by two-digit SIC Code. Entrenchment index i (i=1, 2, 3, 4, and 5-6) is equal to 1 if the firm has an entrenchment level $i$ and 0 otherwise. The other provisions index is equal to the GIM index [Gompers, Ishii, and Metrick (2003)] minus the entrenchment index. Insider Ownership is equal to the fraction of shares held by officers and director. ROA is the ratio of net income to assets. CAPEX/assets is the ratio of capital expenditures to assets. R\&D per Sales is the ratio of research and development expenditures to total sales. Leverage is the ratio of long-term debt plus debt due in one year to assets. Year dummies and a dummy for missing R\&D data are included in all regressions, but their coefficients (as well as the constant) are omitted. Columns 1 and 2 provide OLS estimates, which are White (1980) robust, and Columns 3 and 4 provide the results of regressions with fixed firm effects. Robust standards errors appear below the coefficient estimate. Significance levels are indicated by *, **, and *** for $10 \%, 5 \%$, and $1 \%$ respectively.

\begin{tabular}{|c|c|c|c|c|}
\hline Variable & $(1)$ & $(2)$ & (3) & $(4)$ \\
\hline \multirow[t]{2}{*}{ Entrenchment Index E } & $-0.044^{\star \star \star \pi}$ & & $-0.020^{* \pi}$ & \\
\hline & 0.004 & & 0.007 & \\
\hline \multirow[t]{2}{*}{ Entrenchment Index 1} & & $-0.092^{\star \star \star}$ & & $-0.056^{\star *}$ \\
\hline & & 0.023 & & 0.022 \\
\hline \multirow[t]{2}{*}{ Entrenchment Index 2} & & $-0.146^{\star \star \star}$ & & $-0.065^{\star \star \star}$ \\
\hline & & 0.022 & & 0.025 \\
\hline \multirow[t]{2}{*}{ Entrenchment Index 3} & & $-0.155^{\star \star \star}$ & & $-0.077^{\star \star \star}$ \\
\hline & & 0.022 & & 0.029 \\
\hline \multirow[t]{2}{*}{ Entrenchment Index 4} & & $-0.206^{* *}$ & & $-0.104^{\star \star \star}$ \\
\hline & & 0.023 & & 0.031 \\
\hline \multirow[t]{2}{*}{ Entrenchment Index 5-6 } & & $-0.282^{\star \star \star}$ & & $-0.107^{\star \star \star}$ \\
\hline & & 0.027 & & 0.040 \\
\hline \multirow[t]{2}{*}{ Other Provisions Index } & $0.010^{\star * \star}$ & $0.010^{* * \star}$ & 0.002 & 0.002 \\
\hline & 0.003 & 0.003 & 0.006 & 0.006 \\
\hline \multirow[t]{2}{*}{ Log(Assets) } & $0.015^{\star \star \star *}$ & $0.015^{\star \star \star}$ & $-0.119^{\star \star \star}$ & $-0.118^{\star \star \star}$ \\
\hline & 0.004 & 0.004 & 0.014 & 0.014 \\
\hline \multirow[t]{2}{*}{ Log(Company Age) } & $-0.048^{\star \star *}$ & $-0.047^{\star \star \star}$ & -0.026 & -0.026 \\
\hline & 0.008 & 0.008 & 0.031 & 0.031 \\
\hline \multirow[t]{2}{*}{ Delaware Incorporation } & $-0.03^{* \star \star}$ & $-0.028^{* \star \star}$ & 0.004 & 0.008 \\
\hline & 0.01 & 0.01 & 0.04 & 0.04 \\
\hline \multirow[t]{2}{*}{ Insider Ownership } & 0.001 & 0.001 & $0.005^{\star \star \star}$ & $0.005^{\star *}$ \\
\hline & 0.001 & 0.001 & 0.002 & 0.002 \\
\hline \multirow{2}{*}{ Insider Ownership Square } & -0.00003 & -0.0003 & $-0.0001^{\star}$ & $-0.0001^{*}$ \\
\hline & 0 & 0 & 0 & 0 \\
\hline \multirow[t]{2}{*}{ ROA } & 0.008 & 0.008 & 0.019 & 0.019 \\
\hline & 0.009 & 0.009 & 0.015 & 0.015 \\
\hline \multirow[t]{2}{*}{ CAPEX / Assets } & $0.994^{\star \star \star}$ & $1.00^{\star \star \star}$ & $0.868^{\star \star \star}$ & $0.869^{\star \star \star}$ \\
\hline & 0.089 & 0.09 & 0.120 & 0.120 \\
\hline \multirow[t]{2}{*}{ Leverage } & $-0.544^{\star \star \star}$ & $-0.553^{\star \star \star}$ & $-0.426^{\star \star \star}$ & $-0.427^{\star \star \star}$ \\
\hline & 0.046 & 0.046 & 0.047 & 0.047 \\
\hline \multirow[t]{2}{*}{ R\&D per Sales } & $0.002^{* *}$ & $0.001^{*}$ & $-0.001^{\star \star}$ & $-0.001^{\star *}$ \\
\hline & 0.001 & 0.001 & 0.001 & 0.001 \\
\hline Year fixed effects & Yes & Yes & Yes & Yes \\
\hline Firm fixed effects & No & No & Yes & Yes \\
\hline Number of observations & 8015 & 8015 & 8015 & 8015 \\
\hline R_squared & 0.096 & 0.098 & 0.704 & 0.804 \\
\hline
\end{tabular}




\section{TABLE V: THE ENTRENCHMENT INDEX AND FIRM VALUE: ANNUAL REGRESSIONS}

This table reports mean and median annual OLS regressions of log of industry-adjusted Q and industry-adjusted Q on the entrenchment index and various controls. The data, as in the previous table, consists of 8,015 observations. Industry-adjusted Tobin's q is defined in the same way as in Table 4. The independent variables are the same as in the regressions reported in Table 4, but the table reports only the coefficients of the E index and the O index. FamaMacbeth coefficients are calculated and reported in the last row. Columns 1 and Column 3 provide OLS estimates that are White (1980) robust, and Column 2 provides the results of median regressions. Robust standards errors appear immediately below the coefficient estimate. Levels of significance are indicated by *, **, and $* * *$ for $10 \%$, $5 \%$, and $1 \%$ respectively.

\begin{tabular}{|c|c|c|c|c|c|c|}
\hline & \multicolumn{2}{|c|}{$\begin{array}{c}(1) \\
\log (\text { Industry-adjusted Q) } \\
\text { Mean regressions }\end{array}$} & \multicolumn{2}{|c|}{$\begin{array}{c}(2) \\
\text { Log (Industry-adjusted Q) } \\
\text { Median Regressions }\end{array}$} & \multicolumn{2}{|c|}{$\begin{array}{c}\text { (3) } \\
\text { Industry-adjusted Q } \\
\text { Mean Regressions }\end{array}$} \\
\hline & $\begin{array}{l}\text { Entrenchment } \\
\text { Index }\end{array}$ & $\begin{array}{l}\text { Other } \\
\text { Provisions } \\
\text { Index }\end{array}$ & $\begin{array}{l}\text { Entrenchment } \\
\text { Index }\end{array}$ & $\begin{array}{l}\text { Other } \\
\text { Provisions } \\
\text { Index }\end{array}$ & $\begin{array}{l}\text { Entrenchment } \\
\text { Index }\end{array}$ & $\begin{array}{l}\text { Other } \\
\text { Provisions } \\
\text { Index }\end{array}$ \\
\hline 1992 & -0.011 & 0.003 & -0.009 & -0.001 & -0.028 & -0.002 \\
\hline 1993 & $\begin{array}{c}0.009 \\
-0.018^{*}\end{array}$ & $\begin{array}{c}0.006 \\
-0.003\end{array}$ & $\begin{array}{c}0.016 \\
-0.022^{* *}\end{array}$ & $\begin{array}{c}0.011 \\
-0.007\end{array}$ & $\begin{array}{c}0.021 \\
-0.058^{* *}\end{array}$ & $\begin{array}{c}0.014 \\
-0.011\end{array}$ \\
\hline 1994 & $\begin{array}{c}0.011 \\
-0.018^{* *}\end{array}$ & $\begin{array}{c}0.007 \\
0.004\end{array}$ & $\begin{array}{c}0.010 \\
-0.037^{\text {*** }}\end{array}$ & $\begin{array}{l}0.006 \\
0.001\end{array}$ & $\begin{array}{c}0.027 \\
-0.052^{* *}\end{array}$ & $\begin{array}{c}0.016 \\
0.010\end{array}$ \\
\hline 1995 & $\begin{array}{c}0.009 \\
-0.016\end{array}$ & $\begin{array}{c}0.006 \\
0.0013\end{array}$ & $\begin{array}{c}0.010 \\
-0.023\end{array}$ & $\begin{array}{c}0.007 \\
-0.005\end{array}$ & $\begin{array}{c}0.020 \\
-0.067^{* *}\end{array}$ & $\begin{array}{c}0.014 \\
0.008\end{array}$ \\
\hline 1996 & $\begin{array}{c}0.011 \\
-0.024^{* *}\end{array}$ & $\begin{array}{c}0.008 \\
0.011\end{array}$ & $\begin{array}{c}0.015 \\
-0.025^{*}\end{array}$ & $\begin{array}{c}0.011 \\
-0.002\end{array}$ & $\begin{array}{c}0.032 \\
-0.074^{* *}\end{array}$ & $\begin{array}{c}0.026 \\
0.029\end{array}$ \\
\hline 1997 & $\begin{array}{c}0.01 \\
-0.014^{\star}\end{array}$ & $\begin{array}{c}0.007 \\
0.005\end{array}$ & $\begin{array}{c}0.015 \\
-0.029^{*}\end{array}$ & $\begin{array}{c}0.011 \\
0.017\end{array}$ & $\begin{array}{c}0.029 \\
-0.058^{* *}\end{array}$ & $\begin{array}{c}0.025 \\
0.017\end{array}$ \\
\hline 1998 & $\begin{array}{l}0.008 \\
-0.064^{* * *}\end{array}$ & $\begin{array}{l}0.007 \\
0.022^{* *}\end{array}$ & $\begin{array}{l}0.016 \\
-0.058^{\text {k*k }}\end{array}$ & $\begin{array}{c}0.011 \\
0.000\end{array}$ & $\begin{array}{l}0.027 \\
-0.209^{\text {k*k }}\end{array}$ & $\begin{array}{l}0.022 \\
0.066^{* *}\end{array}$ \\
\hline 1999 & $-0.014{ }^{\star \star \star *}$ & $\begin{array}{c}0.009 \\
0.005\end{array}$ & $\begin{array}{l}0.021 \\
-0.065^{\text {*** }}\end{array}$ & $\begin{array}{l}0.014 \\
0.003\end{array}$ & $\begin{array}{c}0.053 \\
-0.327^{\text {*k* }}\end{array}$ & $\begin{array}{c}0.033 \\
0.015\end{array}$ \\
\hline 2000 & $\begin{array}{l}0.015 \\
-0.03^{\star \star}\end{array}$ & $\begin{array}{c}0.01 \\
0.003\end{array}$ & $\begin{array}{c}0.016 \\
-0.066^{* * *}\end{array}$ & $\begin{array}{c}0.011 \\
-0.003\end{array}$ & $\begin{array}{c}0.077 \\
-0.089^{* \star}\end{array}$ & $\begin{array}{c}0.054 \\
-0.010\end{array}$ \\
\hline 2001 & $\begin{array}{c}0.013 \\
-0.017^{*}\end{array}$ & $\begin{array}{c}0.009 \\
0.006\end{array}$ & $\begin{array}{c}0.020 \\
-0.024^{*}\end{array}$ & $\begin{array}{c}0.014 \\
0.006\end{array}$ & $\begin{array}{c}0.041 \\
-0.044\end{array}$ & $\begin{array}{l}0.028 \\
0.016\end{array}$ \\
\hline 2002 & $\begin{array}{l}0.01 \\
-0.05^{\text {*** }}\end{array}$ & $\begin{array}{c}0.007 \\
0.013^{*}\end{array}$ & $\begin{array}{c}0.014 \\
-0.057^{* \star *}\end{array}$ & $\begin{array}{c}0.010 \\
0.000\end{array}$ & $\begin{array}{c}0.027 \\
-0.119^{\text {*** }}\end{array}$ & $\begin{array}{c}0.019 \\
0.020\end{array}$ \\
\hline & 0.013 & 0.007 & 0.014 & 0.009 & 0.028 & 0.015 \\
\hline Fama-Macbeth & $-0.03^{* \star *}$ & $0.006^{* \star *}$ & $-0.038^{\star \star \star}$ & $0.001^{\star \star \star}$ & $-0.102^{\star \star \star}$ & $0.014^{\star \star \star}$ \\
\hline & 0.006 & 0.002 & 0.006 & 0.002 & 0.027 & 0.006 \\
\hline
\end{tabular}




\section{TABLE VI: THE ENTRENCHMENT INDEX PROVISIONS AND FIRM VALUE}

This table reports the results of 24 pooled OLS regressions of log (industry-adjusted Tobin's q) on provisions in the entrenchment index and various controls. Each table consists of 8,015 observations. Each column displays the results of four different regressions investigating a given provision, and it displays only the coefficient of the provision of interest in these four regressions. The independent variables other than governance provisions are the same as in the regressions of Table 4. OLS estimates are White (1980) robust. Robust standards errors appear immediately below the coefficient estimate. Levels of significance are indicated by *, **, and $* * *$ for $10 \%, 5 \%$, and $1 \%$ respectively.

\begin{tabular}{|c|c|c|c|c|c|c|}
\hline & $\begin{array}{c}\text { Staggered } \\
\text { Board }\end{array}$ & $\begin{array}{c}\text { Golden } \\
\text { Parachutes }\end{array}$ & $\begin{array}{l}\text { Limits } \\
\text { to } \\
\text { Amend } \\
\text { Bylaws }\end{array}$ & $\begin{array}{l}\text { Limits } \\
\text { to } \\
\text { Amend } \\
\text { Charter }\end{array}$ & Supermajority & $\begin{array}{l}\text { Poison } \\
\text { Pill }\end{array}$ \\
\hline $\begin{array}{l}\text { Coefficient in a } \\
\text { regression with (i) the } \\
\text { provision, and (ii) the } \\
\text { GIM index minus the } \\
\text { provision. }\end{array}$ & $\begin{array}{c}-0.035^{\star \star \star} \\
0.011\end{array}$ & $\begin{array}{c}-0.024^{* *} \\
0.012\end{array}$ & $\begin{array}{c}-0.079^{\text {*** }} 0.022\end{array}$ & $\begin{array}{c}-0.048^{\star \star \star} \\
0.01\end{array}$ & $\begin{array}{c}-0.079^{\star * \star} \\
0.0101\end{array}$ & $\begin{array}{c}-0.061^{\star \star \star} \\
0.011\end{array}$ \\
\hline $\begin{array}{l}\text { Coefficient in a } \\
\text { regression with (i) the } \\
\text { provision, (ii) the } \\
\text { entrenchment index } \\
\text { minus the provision, } \\
\text { and (iii) the index of all } \\
\text { other provisions. }\end{array}$ & $\begin{array}{c}-0.051^{\star \star \star} \\
0.005\end{array}$ & $\begin{array}{c}-0.037^{\star \star \star} \\
0.005\end{array}$ & $\begin{array}{c}-0.047^{\star * \star} \\
0.004\end{array}$ & $\begin{array}{c}-0.044^{\star * *} \\
0.004\end{array}$ & $\begin{array}{c}-0.045^{\star \star \star} \\
0.005\end{array}$ & $\begin{array}{c}-0.042^{\star \star \star} \\
0.005\end{array}$ \\
\hline $\begin{array}{l}\text { Coefficient in a } \\
\text { regression with (i) the } \\
\text { provision, (ii) dummies } \\
\text { for each of the other } \\
\text { five provisions in the } \\
\text { entrenchment index, } \\
\text { and (iii) the index of all } \\
\text { other provisions. }\end{array}$ & $\begin{array}{c}-0.026^{* *} \\
0.011\end{array}$ & $\begin{array}{c}-0.025^{\star \star} \\
0.012\end{array}$ & $\begin{array}{c}-0.067^{\star \star \star *} \\
0.021\end{array}$ & $\begin{array}{c}-0.044^{\star * \star} \\
0.01\end{array}$ & $\begin{array}{c}-0.07^{\star \star \star} \\
0.011\end{array}$ & $\begin{array}{c}-0.046^{\star \star \star} \\
0.011\end{array}$ \\
\hline $\begin{array}{l}\text { Coefficient in a } \\
\text { regression with (i) the } \\
\text { provision, (ii) dummies } \\
\text { for each of the other } \\
\text { twenty-three IRRC } \\
\text { provisions. }\end{array}$ & $\begin{array}{c}-0.030^{\star \star \star} \\
0.011\end{array}$ & $\begin{array}{c}-0.026^{\star *} \\
0.012\end{array}$ & $\begin{array}{c}-0.068^{\star \star * \star} \\
0.022\end{array}$ & $\begin{array}{c}-0.043^{\star * \star} \\
0.01\end{array}$ & $\begin{array}{c}-0.071^{\star \star \star} \\
0.011\end{array}$ & $\begin{array}{c}-0.048^{\star \star \star} \\
0.011\end{array}$ \\
\hline
\end{tabular}




\section{TABLE VII: INSIDE THE OTHER PROVISIONS INDEX}

This table reports the results of 72 pooled OLS regressions of log of industry-adjusted Tobin's q on a given provision in the other provisions index and various controls. Industry-adjusted Tobin's Q is defined in the same way as in table 4. Each table consists of 8,015 observations. For each provision i, four types of regressions are run: (1) A regression in which the independent corporate governance variable are the provision $\mathrm{i}$, and a variable equal to the GIM governance provisions index minus the provision i; (2) A regression in which the independent corporate governance variables are the provision $\mathrm{i}$, a variable equal to the other provision index minus the provision $\mathrm{i}$, and the entrenchment index; (3) A regression in which the independent corporate governance variables are the provision i, dummies for each of the other 17 provisions in the other provisions index, and the entrenchment index; and (4) A regression in which the independent corporate governance variables are the provision i and dummies for each of the other 23 IRRC provisions. The independent non-governance variables are the same as in the regressions reported in Table 4. We display only the coefficient on the provision i. OLS estimates are White (1980) robust. Robust standards errors appear immediately below the coefficient estimate. Levels of significance are indicated by *, **, and $* * *$ for $10 \%, 5 \%$, and $1 \%$ respectively.

\begin{tabular}{|c|c|c|c|c|c|c|}
\hline & Blank Check & $\begin{array}{l}\text { Limits to } \\
\text { Meetings }\end{array}$ & $\begin{array}{l}\text { Limits to } \\
\text { Consent }\end{array}$ & $\begin{array}{l}\text { Compensation } \\
\text { Plans }\end{array}$ & $\begin{array}{c}\text { Director } \\
\text { Indemnification } \\
\mathrm{K} \\
\end{array}$ & $\begin{array}{c}\text { Director } \\
\text { Indemnification }\end{array}$ \\
\hline $\begin{array}{l}\text { Regression } \\
\text { Type (1) }\end{array}$ & $\begin{array}{l}0.02 \\
0.014\end{array}$ & $\begin{array}{c}0.025^{* * *} \\
0.011\end{array}$ & $\begin{array}{c}0.001 \\
0.012\end{array}$ & $\begin{array}{c}-0.005 \\
0.011\end{array}$ & $\begin{array}{c}0.031^{* *} \\
0.013\end{array}$ & $\begin{array}{c}0.003 \\
0.01\end{array}$ \\
\hline $\begin{array}{l}\text { Regression } \\
\text { Type (2) }\end{array}$ & $\begin{array}{c}0.025^{*} \\
0.014\end{array}$ & $\begin{array}{c}0.031^{* * *} \\
0.011\end{array}$ & $\begin{array}{c}0.002 \\
0.012\end{array}$ & $\begin{array}{c}0.006 \\
0.011\end{array}$ & $\begin{array}{c}0.031^{* *} \\
0.013\end{array}$ & $\begin{array}{c}-0.011 \\
0.01\end{array}$ \\
\hline $\begin{array}{l}\text { Regression } \\
\text { Type (3) }\end{array}$ & $\begin{array}{c}0.021 \\
0.014\end{array}$ & $\begin{array}{c}0.037^{* * *} \\
0.012\end{array}$ & $\begin{array}{c}-0.001 \\
0.014\end{array}$ & $\begin{array}{c}0.008 \\
0.011\end{array}$ & $\begin{array}{c}0.036^{* * *} \\
0.013\end{array}$ & $\begin{array}{c}-0.011 \\
0.01\end{array}$ \\
\hline $\begin{array}{l}\text { Regression } \\
\text { Type (4) }\end{array}$ & $\begin{array}{c}0.021 \\
0.014 \\
\end{array}$ & $\begin{array}{c}0.034^{* * *} \\
0.012 \\
\end{array}$ & $\begin{array}{c}-0.014 \\
0.013 \\
\end{array}$ & $\begin{array}{c}0.013 \\
0.012 \\
\end{array}$ & $\begin{array}{c}0.035^{* * *} \\
0.013 \\
\end{array}$ & $\begin{array}{c}-0.013 \\
0.01 \\
\end{array}$ \\
\hline & $\begin{array}{c}\text { No Secret } \\
\text { Ballot }\end{array}$ & $\begin{array}{l}\text { Unequal } \\
\text { Vote }\end{array}$ & $\begin{array}{c}\text { Anti } \\
\text { Greenmail }\end{array}$ & $\begin{array}{c}\text { Director } \\
\text { Duties }\end{array}$ & Fair Price & $\begin{array}{c}\text { Pension } \\
\text { Parachutes }\end{array}$ \\
\hline $\begin{array}{l}\text { Regression } \\
\text { Type (1) }\end{array}$ & $\begin{array}{c}0.028^{*} \\
0.014\end{array}$ & $\begin{array}{c}-0.048 \\
0.032\end{array}$ & $\begin{array}{c}-0.008 \\
0.013\end{array}$ & $\begin{array}{c}-0.004 \\
0.015\end{array}$ & $\begin{array}{c}0.038^{* * *} \\
0.012\end{array}$ & $\begin{array}{c}-0.049^{* *} \\
0.021\end{array}$ \\
\hline $\begin{array}{l}\text { Regression } \\
\text { Type (2) }\end{array}$ & $\begin{array}{l}0.034^{* *} \\
0.014\end{array}$ & $\begin{array}{c}-0.04 \\
0.032\end{array}$ & $\begin{array}{c}-0.001 \\
0.012\end{array}$ & $\begin{array}{c}0.005 \\
0.015\end{array}$ & $\begin{array}{c}0.032^{* * *} \\
0.012\end{array}$ & $\begin{array}{c}-0.037^{*} \\
0.021\end{array}$ \\
\hline $\begin{array}{l}\text { Regression } \\
\text { Type (3) }\end{array}$ & $\begin{array}{l}0.032^{* *} \\
0.015\end{array}$ & $\begin{array}{c}-0.03 \\
0.033\end{array}$ & $\begin{array}{c}-0.012 \\
0.013\end{array}$ & $\begin{array}{l}0.01 \\
0.015\end{array}$ & $\begin{array}{l}0.03^{* *} \\
0.012\end{array}$ & $\begin{array}{c}-0.035^{*} \\
0.021\end{array}$ \\
\hline $\begin{array}{l}\text { Regression } \\
\text { Type (4) }\end{array}$ & $\begin{array}{c}0.03^{5 * *} \\
0.015 \\
\end{array}$ & $\begin{array}{c}-0.035 \\
0.033 \\
\end{array}$ & $\begin{array}{c}-0.009 \\
0.013 \\
\end{array}$ & $\begin{array}{c}0.004 \\
0.015 \\
\end{array}$ & $\begin{array}{c}0.027^{* * *} \\
0.013 \\
\end{array}$ & $\begin{array}{c}-0.031 \\
0.021 \\
\end{array}$ \\
\hline & $\begin{array}{c}\text { No } \\
\text { Cumulative } \\
\text { Vote }\end{array}$ & $\begin{array}{l}\text { Director } \\
\text { Liability }\end{array}$ & $\begin{array}{c}\text { Business } \\
\text { Combination }\end{array}$ & $\begin{array}{c}\text { Silver } \\
\text { Parachutes }\end{array}$ & Cash-Out & $\begin{array}{c}\text { Severance } \\
\text { Agreements }\end{array}$ \\
\hline $\begin{array}{l}\text { Regression } \\
\text { Type (1) }\end{array}$ & $\begin{array}{l}-0.017 \\
0.013\end{array}$ & $\begin{array}{c}0.003 \\
0.011\end{array}$ & $\begin{array}{l}0.021^{* *} \\
0.016\end{array}$ & $\begin{array}{c}0.017 \\
0.021\end{array}$ & $\begin{array}{c}0.026 \\
0.029\end{array}$ & $\begin{array}{c}0.038^{* *} \\
0.020\end{array}$ \\
\hline $\begin{array}{l}\text { Regression } \\
\text { Type (2) }\end{array}$ & $\begin{array}{c}-0.005 \\
0.012\end{array}$ & $\begin{array}{c}-0.013 \\
0.011\end{array}$ & $\begin{array}{c}0.024 \\
0.016\end{array}$ & $\begin{array}{c}0.015 \\
0.022\end{array}$ & $\begin{array}{c}-0.000 \\
0.028\end{array}$ & $\begin{array}{c}0.022 \\
0.020\end{array}$ \\
\hline $\begin{array}{l}\text { Regression } \\
\text { Type (3) }\end{array}$ & $\begin{array}{c}-0.007 \\
0.013\end{array}$ & $\begin{array}{c}-0.006 \\
0.011\end{array}$ & $\begin{array}{c}0.025 \\
0.017\end{array}$ & $\begin{array}{c}0.021 \\
0.022\end{array}$ & $\begin{array}{c}-0.003 \\
0.03\end{array}$ & $\begin{array}{c}0.021 \\
0.020\end{array}$ \\
\hline $\begin{array}{l}\text { Regression } \\
\text { Type (4) }\end{array}$ & $\begin{array}{c}-0.005 \\
0.012\end{array}$ & $\begin{array}{c}-0.004 \\
0.011\end{array}$ & $\begin{array}{c}0.026 \\
0.017\end{array}$ & $\begin{array}{c}0.019 \\
0.022\end{array}$ & $\begin{array}{c}0.001 \\
0.013\end{array}$ & $\begin{array}{l}0.01 \\
0.021\end{array}$ \\
\hline
\end{tabular}




\section{TABLE VIII}

THE ENTRENCHMENT INDEX AND FIRM VALUE 1998-2002

This table reports pooled OLS regressions of log (industry-adjusted Tobin's q) for 1998-2002 on various controls and two specifications of the entrenchment index. The calculation of industry-adjusted Tobin's Q is described in Table 4. In addition to the controls used earlier in the Table 4 regressions, Columns 1 and 3 control for firms' 1990 entrenchment index scores, while columns 2 and 4 control for the different levels of firms' 1990 entrenchment index scores. Moreover, Columns 3 and 4 control for the log of firms' industry-adjusted Tobin's Q as of 1990 . Year dummies and a dummy for missing R\&D data are included in all regressions, but their coefficients (as well as the constant) are omitted. White (1980) robust standards errors appear below the coefficient estimate. Significance levels are indicated by *, **, and $* * *$ for $10 \%, 5 \%$, and $1 \%$ respectively.

\begin{tabular}{|c|c|c|c|c|}
\hline Variable & (1) & (2) & (3) & (4) \\
\hline \multirow[t]{2}{*}{ Entrenchment Index E 90} & $-0.024^{\star \star \star}$ & & $-0.017^{\star \star \star}$ & \\
\hline & 0.005 & & 0.005 & \\
\hline \multirow[t]{2}{*}{ Entrenchment Index 190} & & -0.045 & & -0.036 \\
\hline & & 0.031 & & 0.03 \\
\hline \multirow[t]{2}{*}{ Entrenchment Index 290} & & $-0.073^{\star *}$ & & $-0.075^{\star \star x}$ \\
\hline & & 0.029 & & 0.027 \\
\hline \multirow[t]{2}{*}{ Entrenchment Index 390} & & $-0.071^{* *}$ & & $-0.054^{* *}$ \\
\hline & & 0.029 & & 0.028 \\
\hline \multirow[t]{2}{*}{ Entrenchment Index 490} & & $-0.122^{\star \star \star}$ & & $-0.092^{* \star x /}$ \\
\hline & & 0.03 & & 0.028 \\
\hline \multirow[t]{2}{*}{ Entrenchment Index 5-690 } & & $-0.105^{\star \star \star}$ & & $-0.078^{* *}$ \\
\hline & & 0.039 & & 0.036 \\
\hline \multirow[t]{2}{*}{ Other Provisions Index } & 0.002 & 0.002 & 0.002 & 0.002 \\
\hline & 0.004 & 0.004 & 0.004 & 0.004 \\
\hline Log (Industry-Adjusted Q) 90 & & & $\begin{array}{l}.289^{\star \star \star \star} \\
.025\end{array}$ & $\begin{array}{l}.291^{\star \star *} \\
.025\end{array}$ \\
\hline \multirow[t]{2}{*}{ Log(Assets) } & $0.049^{* * *}$ & 0.049 & $0.045^{* \star \star}$ & $0.044^{\star \star \star}$ \\
\hline & 0.005 & 0.005 & 0.005 & 0.005 \\
\hline \multirow[t]{2}{*}{ Log(Company Age) } & $-0.036^{\star \star}$ & $-0.032^{*}$ & -0.016 & -0.01 \\
\hline & 0.017 & 0.017 & 0.018 & 0.017 \\
\hline \multirow[t]{2}{*}{ Delaware Incorporation } & -0.021 & -0.02 & -.017 & -.015 \\
\hline & 0.015 & 0.015 & 0.014 & 0.014 \\
\hline \multirow[t]{2}{*}{ Insider Ownership } & $-0.004^{*}$ & $0.005^{*}$ & -0.003 & -.003 \\
\hline & 0.003 & 0.003 & 0.002 & 0.002 \\
\hline \multirow[t]{2}{*}{ Insider Ownership Square } & 0 & 0 & 0 & 0 \\
\hline & 0 & 0 & 0 & 0 \\
\hline \multirow[t]{2}{*}{ ROA } & $2.859^{\star \star \star *}$ & $2.859^{\star \star \star}$ & $2.457^{\star \star \star}$ & $2.456^{\star * \star}$ \\
\hline & 0.134 & 0.134 & 0.147 & 0.147 \\
\hline \multirow[t]{2}{*}{ CAPEX / Assets } & $0.173^{* \star *}$ & $.729^{\star \star \star}$ & $0.847^{\star \star \star}$ & $0.87^{\star \star \star}$ \\
\hline & 0.167 & 0.031 & 0.16 & 0.162 \\
\hline \multirow[t]{2}{*}{ Leverage } & $-0.403^{\star \star \star}$ & $-0.405^{\star \star \star}$ & $-0.31^{\star \star *}$ & $0.312^{\star \star *}$ \\
\hline & 0.058 & 0.058 & 0.059 & 0.059 \\
\hline \multirow[t]{2}{*}{ R\&D per Sales } & $1.218^{\star \star \star *}$ & $1.28^{\star \star \star}$ & $0.909^{\star * \star}$ & $0.934^{\star * \star}$ \\
\hline & 0.242 & 0.242 & 0.242 & 0.242 \\
\hline Year fixed effects & Yes & Yes & Yes & Yes \\
\hline Number of observations & 2173 & 2173 & 2157 & 2157 \\
\hline R_squared & 0.4833 & 0.4840 & 0.5219 & 0.5230 \\
\hline
\end{tabular}


This table documents the average monthly return of stocks of portfolios of stocks consisting of the same entrenchment index scores (0, 1, 2, 3, 4 or 5-6) for the period of September 1990-December 1999. Portfolios are constructed using equal weights of stocks and weighting positions in stocks by firms' common stock market capitalization. Firms' entrenchment scores were adjusted when updated information on firms' corporate governance provisions became available: July, 1993; July, 1995; and February 1998.

\begin{tabular}{lcc} 
& $\begin{array}{c}\text { Equal- } \\
\text { Weight }\end{array}$ & $\begin{array}{c}\text { Value- } \\
\text { Weight }\end{array}$ \\
\hline Entrenchment Index Level & & \\
Index 5-6 & $1.26 \%$ & $1.51 \%$ \\
Index 4 & $1.40 \%$ & $1.85 \%$ \\
Index 3 & $1.46 \%$ & $1.93 \%$ \\
Index 2 & $1.59 \%$ & $2.26 \%$ \\
Index 1 & $1.72 \%$ & $2.33 \%$ \\
Index 0 & $1.74 \%$ & $2.45 \%$
\end{tabular}




\section{TABLE X \\ MONTHLY ABNORMAL RETURNS ASSOCIATED WITH DIFFERENT TRADING STRATEGIES: THE 1990s}

This table documents the monthly abnormal returns, and their associated robust standard errors in parenthesis, associated with different trading strategies for the period of September 1990-December 1999. The monthly abnormal returns where calculated using three different methods. In the baseline model, abnormal returns were calculated by regressing the return associated with a particular trading strategy on the three Fama-French [Fama and French (1993)]-book-to-market stock effects, firm size stock effects, and market stock effects-and a momentum factor that was calculated using the procedures described in Carhart (1997). The trading strategies analyzed consist of going long a portfolio of stocks with a certain entrenchment index score and, simultaneously, shorting another portfolio of stocks with a higher entrenchment score. These long and short portfolios were adjusted when updated information on firms' corporate governance provisions became available: July, 1993; July, 1995; and February 1998. The long and short portfolios of stocks were constructed using equal weightings of each stock (equal-weight) and by weighting the holding of a stock in the portfolio by its common stock market capitalization (value-weight). With industry-adjusted returns, the monthly abnormal returns were calculated by first subtracting from each firm's monthly stock return the median industry return for the industry in which the firm operates. The Fama-French 48 industry classification [Fama and French (1997)] was used in classifying firms across industries. Monthly abnormal returns were then calculated by regressing the industry-adjusted returns associated with a trading strategy on the four Carhart (1997) factors used in the baseline model. Finally, with the O-Bucket-Adjusted returns, the long and short portfolios were constructed by first dividing all stocks into four buckets consisting of firms with O scores of 0-5, 6, 7-8, and 9-13. Then, the return on going long firms with a certain E score and short firms with a certain E score (either equally-weighted or value-weighted) within each bucket was calculated with an overall long-short portfolio consisting of an equally-weighted position in each of the four long and short positions created for the four $\mathrm{O}$ buckets. The O Bucket-adjusted returns associated with a particular trading strategy was regressed, as always, on the four Carhart factors. Levels of significance are indicated by *, **, and *** for $10 \%, 5 \%$, and $1 \%$ respectively.

\section{Baseline Model Industry-adjusted O-Bucket-Adjusted}

\begin{tabular}{|c|c|c|c|c|c|c|}
\hline Long - Short Portfolios & $\begin{array}{l}\text { Equal- } \\
\text { Weight }\end{array}$ & $\begin{array}{l}\text { Value- } \\
\text { Weight }\end{array}$ & $\begin{array}{l}\text { Equal- } \\
\text { Weight }\end{array}$ & $\begin{array}{l}\text { Value- } \\
\text { Weight }\end{array}$ & $\begin{array}{l}\text { Equal- } \\
\text { Weight }\end{array}$ & $\begin{array}{l}\text { Value- } \\
\text { Weight }\end{array}$ \\
\hline Index $0-$ Index 5-6 & $\begin{array}{l}.61^{\star \star \star} \\
(.200)\end{array}$ & $\begin{array}{l}1.16^{\star \star \star} \\
(.284)\end{array}$ & $\begin{array}{l}.60^{\star \star \star} \\
(.182)\end{array}$ & $\begin{array}{l}1.01^{\star \star \star} \\
(.301)\end{array}$ & $\begin{array}{l}.73^{\star \star \star} \\
(.269)\end{array}$ & $\begin{array}{l}1.16^{\star \star \star} \\
(.298)\end{array}$ \\
\hline Index 0 - Index 4-5-6 & $\begin{array}{l}.42^{\star \star \star} \\
(.134)\end{array}$ & $\begin{array}{l}.74^{\star \star \star} \\
(.191)\end{array}$ & $\begin{array}{l}.47^{\star \star \star} \\
(.116)\end{array}$ & $\begin{array}{l}.82^{\star \star \star} \\
(.198)\end{array}$ & $\begin{array}{l}.61^{\star \star \star} \\
(.195)\end{array}$ & $\begin{array}{l}.89 * \star \star \\
(.210)\end{array}$ \\
\hline Index 0-1 - Index 4-5-6 & $\begin{array}{l}.41^{\star \star *} \\
(.138)\end{array}$ & $\begin{array}{l}.62^{\star \star \star} \\
(.153)\end{array}$ & $\begin{array}{l}.44^{\star \star \star} \\
(.109)\end{array}$ & $\begin{array}{l}.62^{\star \star \star} \\
(.154)\end{array}$ & $\begin{array}{l}.34^{\star *} \\
(.141)\end{array}$ & $\begin{array}{l}.77^{\star \star \star} \\
(.180)\end{array}$ \\
\hline Index 0-1 - Index 3-4-5-6 & $\begin{array}{l}.32^{\star \star \star} \\
(.106)\end{array}$ & $\begin{array}{l}.52^{\star \star \star} \\
(.141)\end{array}$ & $\begin{array}{l}.34^{\star \star \star} \\
(.088)\end{array}$ & $\begin{array}{l}.57^{\star \star \star} \\
(.130)\end{array}$ & $\begin{array}{l}.28^{\star \star \star} \\
(.107)\end{array}$ & $\begin{array}{l}.58^{\star \star \star} \\
(.161)\end{array}$ \\
\hline Index 0-1-2-Index 3-4-5-6 & $\begin{array}{l}.25^{\star \star \star} \\
(.079)\end{array}$ & $\begin{array}{l}.47^{\star \star \star} \\
(.116)\end{array}$ & $\begin{array}{l}.26^{\star \star \star} \\
(.067)\end{array}$ & $\begin{array}{l}.51^{\star \star \star} \\
(.108)\end{array}$ & $\begin{array}{l}.23^{\star \star \star} \\
(.071)\end{array}$ & $\begin{array}{l}.50^{\star \star *} \\
(.123)\end{array}$ \\
\hline
\end{tabular}




\section{TABLE XI \\ MONTHLY ABNORMAL RETURNS ASSOCIATED WITH DIFFERENT TRADING STRATEGIES: \\ 1990-2003}

This table documents the monthly abnormal returns, and their associated robust standard errors in parenthesis, associated with different trading strategies for the period of September 1990-December 2003. The abnormal returns were calculated in the same manner as in Table 10: the baseline model, industry-adjusted returns, and O Bucketadjusted returns. The long and short portfolios were adjusted when updated information on firms' corporate governance provisions became available: July, 1993; July, 1995; February 1998; November, 1999; and February 2002. The long and short portfolios of stocks were constructed using equal weightings of each stock (equal-weight) and by weighting the holding of a stock in the portfolio by its common stock market capitalization (value-weight). Levels of significance are indicated by *, **, and $* * *$ for $10 \%, 5 \%$, and $1 \%$ respectively.

\section{Baseline Model Industry-adjusted O-Bucket-Adjusted}

\begin{tabular}{|c|c|c|c|c|c|c|}
\hline Long - Short Portfolios & $\begin{array}{l}\text { Equal- } \\
\text { Weight }\end{array}$ & $\begin{array}{l}\text { Value- } \\
\text { Weight }\end{array}$ & $\begin{array}{l}\text { Equal- } \\
\text { Weight }\end{array}$ & $\begin{array}{l}\text { Value- } \\
\text { Weight }\end{array}$ & $\begin{array}{l}\text { Equal- } \\
\text { Weight }\end{array}$ & $\begin{array}{l}\text { Value- } \\
\text { Weight }\end{array}$ \\
\hline Index 0 - Index 5-6 & $\begin{array}{l}.60^{\star \star \star} \\
(.185)\end{array}$ & $\begin{array}{l}.84^{\star \star \star} \\
(.224)\end{array}$ & $\begin{array}{l}.66^{\star \star \star} \\
(.156)\end{array}$ & $\begin{array}{l}.94^{\star \star \star} \\
(.230)\end{array}$ & $\begin{array}{l}.68^{\star \star \star} \\
(.220)\end{array}$ & $\begin{array}{l}.81^{\star \star \star} \\
(.246)\end{array}$ \\
\hline Index 0 - Index 4-5-6 & $\begin{array}{l}.39 \star \star \star \\
(.145)\end{array}$ & $\begin{array}{l}.57^{\star \star \star} \\
(.186)\end{array}$ & $\begin{array}{l}.48^{\star \star \star} \\
(.125)\end{array}$ & $\begin{array}{l}.67^{\star \star \star} \\
(.185)\end{array}$ & $\begin{array}{l}.50 \star \star \star \\
(.169)\end{array}$ & $\begin{array}{l}.60^{\star \star \star} \\
(.206)\end{array}$ \\
\hline Index 0-1 - Index 4-5-6 & $\begin{array}{l}.42^{\star \star \star} \\
(.133)\end{array}$ & $\begin{array}{l}.52^{\star \star \star} \\
(.157)\end{array}$ & $\begin{array}{l}.52^{\star \star \star} \\
(.114)\end{array}$ & $\begin{array}{l}.53^{\star \star \star} \\
(.151)\end{array}$ & $\begin{array}{l}.35^{\star \star \star} \\
(.130)\end{array}$ & $\begin{array}{l}.58^{\star \star \star} \\
(.179)\end{array}$ \\
\hline Index 0-1 - Index 3-4-5-6 & $\begin{array}{l}.37^{\star \star \star} \\
(.107)\end{array}$ & $\begin{array}{c}.41^{\star \star \star} \\
(.132)\end{array}$ & $\begin{array}{l}.43^{\star \star \star} \\
(.090)\end{array}$ & $\begin{array}{l}.46^{\star \star \star} \\
(.125)\end{array}$ & $\begin{array}{l}.34^{\star \star \star} \\
(.100)\end{array}$ & $\begin{array}{l}.43^{\star \star \star} \\
(.144)\end{array}$ \\
\hline Index 0-1-2-Index 3-4-5-6 & $\begin{array}{l}.27^{\star \star \star} \\
(.085)\end{array}$ & $\begin{array}{l}.37^{\star \star \star} \\
(.117)\end{array}$ & $\begin{array}{l}.34^{\star \star \star} \\
(.070)\end{array}$ & $\begin{array}{l}.39 * \star \star \\
(.110)\end{array}$ & $\begin{array}{l}.24^{\star \star \star} \\
(.074)\end{array}$ & $\begin{array}{l}.38^{\star \star \star} \\
(.121)\end{array}$ \\
\hline
\end{tabular}




\section{TABLE XII \\ MONTHLY ABNORMAL RETURNS ASSOCIATED WITH DIFFERENT TRADING STRATEGIES \\ CONTROLLING FOR ENTRENCHMENT INDEX DISTRIBUTION}

This table documents the monthly abnormal returns, and their associated t-statistics in parenthesis, associated with trading strategies controlling, as in Table 10 and 11, for the three Fama-French factors [Fama and French (1993)] and the Carhart (1997) momentum factor. Portfolios are constructed by first dividing all stocks in the same other provisions (O) category, $0-5,6,7-8$, or $9-13$, into six entrenchment index categories. The six entrenchment index buckets are entrenchment index scores of $0,1,2,3,4$ and 5-6. A portfolio in a certain $\mathrm{O}$ index category is then constructed by calculating the equally-weighted return of stocks with the desired $\mathrm{O}$ index category across the six entrenchment buckets. Within each bucket, the equally-weighted and value-weighted return of stocks in the same $\mathrm{O}$ category were calculated. The monthly abnormal returns associated with going long and short various portfolios was calculated for both the period of September 1990-December 1999 period and the longer period of September 1990December 2003. The long and short portfolios were adjusted when updated information on firms' corporate governance provisions became available: July, 1993; July, 1995; February 1998; November, 1999; and February 2002. Levels of significance are indicated by *, **, and $* * *$ for $10 \%, 5 \%$, and $1 \%$ respectively.

\begin{tabular}{|c|c|c|c|c|}
\hline & \multicolumn{2}{|c|}{ 1990-1999 } & \multicolumn{2}{|c|}{$1990-2003$} \\
\hline & $\begin{array}{l}\text { Equal- } \\
\text { Weight }\end{array}$ & $\begin{array}{l}\text { Value- } \\
\text { Weight }\end{array}$ & $\begin{array}{l}\text { Equal- } \\
\text { Weight }\end{array}$ & $\begin{array}{l}\text { Value- } \\
\text { Weight }\end{array}$ \\
\hline \multicolumn{5}{|l|}{ Long - Short Portfolios } \\
\hline Index 0-5 - Index 9-13 & $\begin{array}{c}.10 \\
(.162)\end{array}$ & $\begin{array}{c}.13 \\
(.180)\end{array}$ & $\begin{array}{c}.07 \\
(.133)\end{array}$ & $\begin{array}{c}.05 \\
(.146)\end{array}$ \\
\hline Index 0-5 - Index 7-8 & $\begin{array}{c}-.024 \\
(.143)\end{array}$ & $\begin{array}{c}.08 \\
(.124)\end{array}$ & $\begin{array}{c}.03 \\
(.124)\end{array}$ & $\begin{array}{c}.17 \\
(.106)\end{array}$ \\
\hline Index 0-5 - Index 6 & $\begin{array}{c}-.10 \\
(.148)\end{array}$ & $\begin{array}{c}-.01 \\
(.155)\end{array}$ & $\begin{array}{c}-.04 \\
(.136)\end{array}$ & $\begin{array}{c}-.05 \\
(.141)\end{array}$ \\
\hline Index 0-6 - Index 7-13 & $\begin{array}{l}.10 \\
(.107)\end{array}$ & $\begin{array}{c}.02 \\
(.056)\end{array}$ & $\begin{array}{c}.07 \\
(.096)\end{array}$ & $\begin{array}{c}.05 \\
(.051)\end{array}$ \\
\hline
\end{tabular}

